九州大学学術情報リポジトリ

Kyushu University Institutional Repository

\title{
Opisthobranchia Of Japan (II)
}

Baba, Kikutaro

The Amakusa Marine Biological Laboratory, Tomioka, Kumamoto-ken.

https://doi.org/10.5109/22586

出版情報：九州大学大学院農学研究院紀要. 5 (7)，pp. 289-344，1937-11. Kyushu Imperial University バージョン：

権利関係 : 
Journal of the Department of Agriculture, Kyûshû Imperial University, Vol. 5, No. 7,

November 20, 1937

\title{
OPISTHOBRANCHIA OF JAPAN (II) ${ }^{1)}$
}

\author{
Kikutarô BABA
}

\author{
Suborder Nudibranchia \\ Tribe 1. Holohepatica (= Doridacea) \\ Family Hexabranchidae \\ Genus Hexabranchus EHrenBerg, 1831
}

Hexabranchus Ehrengerg, Symb. phys., 1831.

Type: Hexabranchus praetextus EHRENBERG.

34. Hexabranchus marginatus (QUOY \& GAIMARD, 1832)

Family Euphuridae (= Polyceridae)

Subfamily Euphurinae

Genus Euphurus RafinESQUE, 1815

Euphurus RafiNesque, Analyse Nature, 1815, p. 142.

Triopa Joнмsтs:, Ann. Nat. Hist., vol. 1, 1838, p. 123.

Type: Doris clavigera O. F. MÜLler.

35. Euphurus ornatus nov. sp.

(P1. 2, fig. 8)

Distribution in Japan: Tateyama and Seto (Kii).

The living animal is limaciform, measuring about $10 \mathrm{~mm}$ in length. The back is smooth save for the presence of about a dozen small blunt tubercles in rather regular rows. It is marked off from

1) Contributions from the Zoological Laboratory, Kyûshû Imperial University, No. 108. Papers from the Amahusa Marine Biological Laboratory, No. 62. 
sides by a series of 7 processes consisting of an ovoid body with a short stalk. The perfoliate rhinophores are retractile within low sheaths with an entire margin. The non-retractile branchiae, 3-4 in number, are simply pinnate, and lie closely in front of the anus. The margin of the head veil bears 4.5 processes similar in shape to those along the edge of the body but having small granules towards the top. The oral tentacles are canaliculiform. The anterior edge of the foot is abruptly truncated.

The general body colour is yellowish white beautifully ornamented with tiny orange spots. The rhinophores are dull yellow tipped with vermilion.

Localities: Tateyama (May 1925; 1 sp.) and Seto (Apr. 1937; 2 sps., coll. by Mr. F. HiRo).

This species is especially characteristic in the shape of the processes along the edge of the head and back. It has also an unmistakable coloration.

Genus Polycera Cuvier, 1817

Polycera Cuver, Règne Animal, tom. 2, 1817, p. 389.

Type: Doris quadrilineata O. F. MǗLER.

36. Polycera fujitai nov. sp.

(Text-fig. 1)

Distribution in Japan: Tomioka (Amakusa).

The animal in life is limaciform and measures up to $45 \mathrm{~mm}$ in length. The rhinophore consists of a long stalk and a small perfoliate clavus, and is without a sheath. The branchiae, 7 in number, are tripinnate and arranged in little more than a semicircle, about half way back. The hinder part of the circle is occupied by the anus. The frontal veil is slightly expanded, and bears 6.10 simple digitiform processes. The back margin is distinct, having a row of small subconical papillae. Similar ones are also distributed on the back, sides and tail crest. The genital orifice lies on the right side a short distance behind the head. The oral tentacles are lobiform. The antero-lateral corners of the foot are slightly produced into obtuse points.

The ground colour of the body is translucent yellowish white, but it is almost everywhere obscured by black speckles and also by irregular streaks of yellowish brown and dark. The stalk of 
the rhinophore is dark, the clavus black and the tip white. The dermal papillae tipped with light yellow. The sole uniformly yellowish white.

The jaw-plates are well-developed and of a horn-yellow colour. They are approximately triangular in outline, and the anterior edge
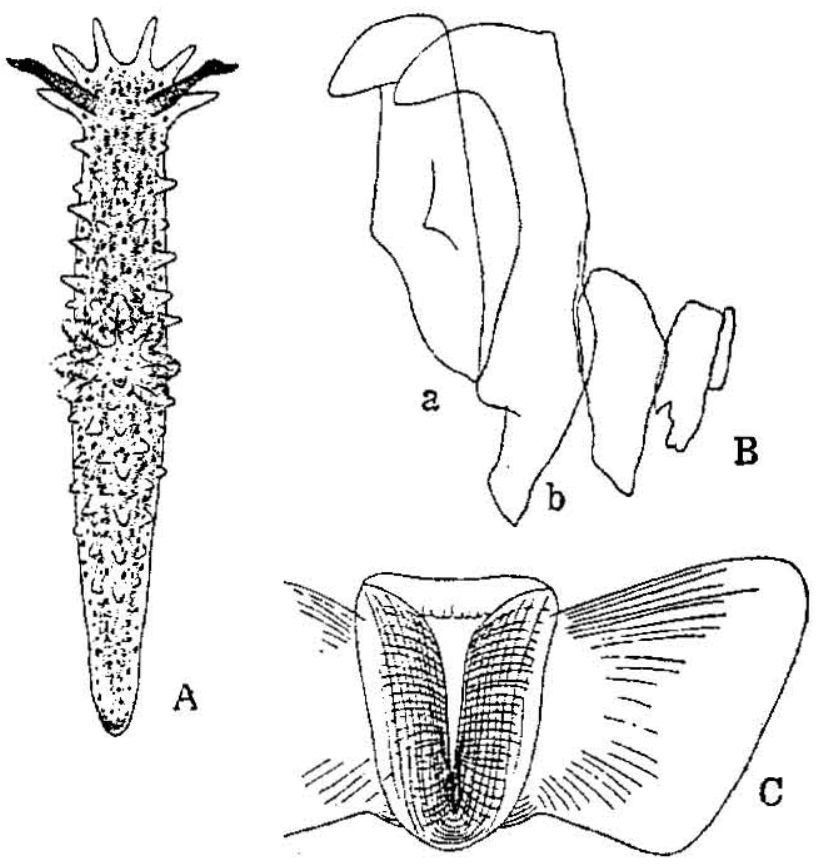

Text-fig. 1.-Polycera fujitai. A. Dorsal view of entire animal $(\times 1.5)$; B. A half-row of radula $(\times 70)$, a. Ist lateral tooth b. 2nd tooth; C. A pair of jaw-plates, in frontal lateral view (x 10).

is continued out into wing-like flange which stands laterally recurved. The radula is of a characteristic black-brown, consisting of about 10-13 rows, 4-5 in each half-row, and may be formulated as $10(-13) \times 4 \cdot 5 \cdot 0.4-5$. The 1 st lateral tooth is roughly hamate with a blunt spine about half way down. The 2nd lateral tooth is larger and is simply hamate. The succeeding teeth, $2 \cdot 3$ in number, are much reduced to become scale-like plates.

Locality: Tomioka (Jan. 1933; fairly common on Zostera).

The present species resembles a Vancouver Island Nudibranch, Polycera zosterae O'DoNOGHUE, in the habitat and external form, but is distinguished from that form by having a different coloration, much more numerous branchiae and fewer lateral teeth. It is here, named P. fujitai in honour of Dr. Tsunenobu FujITA. 


\section{Genus Gymnodoris StImpson, 1855}

Gymnodoris Strupsux, Proc. Acad. Nat. Sci. Philadelphia, 1855, p. 379.

Trevelyana K=LAar!, Ann. Mag. Nat. Hist., ser. 3, vol. 1, 1858, p. 257.

Type: Gymnodoris maculata Stimpson.

Synopsis of the Iapanese species:

A. Branchiae in a transverse crescentic row ...

B. Branchiae in a circular or a horseshoe row.

1. Innermost lateral tooth larger than the succeeding teeth.

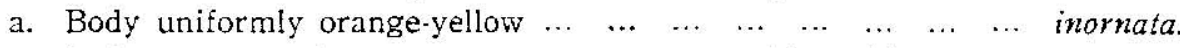

b. Body yellow with orange spots, sometimes white with yellow or orange $\begin{array}{lllllllllllllll}\text { spots } \ldots & \ldots & \ldots & \ldots & \ldots & \ldots & \ldots & \ldots & \ldots & \ldots & \ldots & \ldots & \ldots & \ldots & \text { citrina. }\end{array}$

2. Innermost lateral tooth smaller than the succeeding teeth.

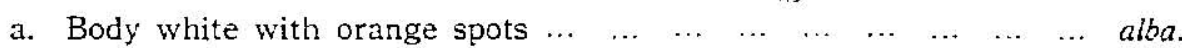

b. Body yellowish with orange-yellow spots and streaks $\ldots \quad \ldots$ okinawae.

37. Gymnodoris maculata STIMPSON, 1855

38. Gymnodoris citrina (BERGH, 1877)

(Pl. 1, fig. 9)

By examining many specimens of Gymnodoris japonica (BABA)

I have found that this is identical with G. citrina (BERGH), the 2nd lateral tooth of the radula showing no constant specific difference. In some specimens the tooth in question has a small basal denticle, but in others it is entirely smooth.

39. Gymnodoris alba (BERGH, 1877)

40. Gymnodoris inornata (BERGH, 1880)

(Pl. 1, fig. 8)

41. Gymnodoris striata (ELIOT, 1908)

42. Gymnodoris okinawae BABA, 1936

Genus Nembrotha BERGH, 1877

Nembrotha Bergh, Malac. Unters., Hft. 11, 1877, p. 450.

Type: Nembrotha nigerrima BERGH.

43. Nembrotha luteolineata BABA, 1936

Genus Caloplocamus BERGH, 1879

Euplocamus Putctppt, Enum. Moll. Siciliae, 1, 1836, p. 103. 
Kaloplocamus BERst, Verh. k. k. zool.-bot. Gesell. Wien, Bd. 29, 1879, p. 623, foot-note. Caloplocamus THete, Handb. syst. Weicht., Th. 2, 1931, p. 425.

Type: Euplocamus croceus PhiLIPPI.

44. Caloplocamus ramosus (CANTRAINe, 1835) ${ }^{12}$

Genus Plocamophorus RüpPell \& LeUCKaRT, 1828

Plocamopherus Rïppelt \& Leuckart, Wirbellose Thiere, 1828, p. 17.

Type: Plocamopherus ocellatus RÜPPELL \& LEUCKART.

a. First lateral tooth bicuspid, the succeeding inner teeth simply hamate. Body yellow or orange yellow thickly covered with chocolate mottles $\ldots$ imperialis.

b. Inner lateral teeth roughly bicuspid. Body yellowish shaded with chocolate, and almost everywhere scattered with deep chocolate and chrome-yellow spots $\begin{array}{lllllllllll}\ldots & \ldots & \ldots & \ldots & \ldots & \ldots & \ldots & \ldots & \ldots & \ldots & \text { tilesii. }\end{array}$

45. Plocamophorus imperialis ANGas, 1864

Plocamophorus imperialis Angas, Journ. Conchyl., Paris, tom. 12, 1864, pp. 59.60, pl. 5, fig. 7.-Vaucluse (Australia).

Plocamopherus imperialis Euror, Journ. Coll. Sci. Imp. Univ. Tôkyô, vol. 35, art. 1, 1913, p. 30.-Japan.

Locality: Seto, Kii (Mar. 1937; 2 sps.).

46. Plocamophorus tilesii BERGH, 1877

47. Plocamophorus sp. HiRasé, 1927

Plocamophorus sp. Hirasé, Moluskoj, 1927, p. 1472, fig. 2832.-Misaki.

Genus Kalinga Alder \& Hancock, 1864

Kalinga Azder \& Havenck, Trans. Zool. Soc. London, vol. 5, pt. 3, 1864, pp. 134-135.

Type: Kalinga ornata AldeR \& HaNCOCK.

48. Kalinga ornata ALDER \& HANCOCK, 1864

Subfamily Acanthodoridinae

Genus Acanthodoris GraY, 1850

Acanthodoris GraY, Figs. Molluse. Anim., vol. 4, 1850, p. 103.

Type: Doris pilosa ABILDGaARD.

1) Sỵnonym: C. croceus (Phuturt), see O'Doxochue (1929, p. 775), 
Synopsis of the Japanese species:

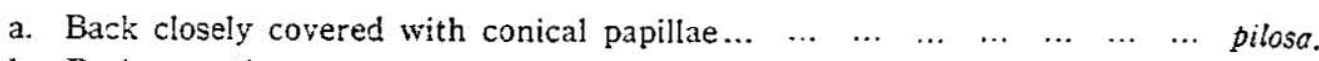

$\begin{array}{lllllllllllllllll}\text { b. Back smooth } & \ldots & \ldots & \ldots & \ldots & \ldots & \ldots & \ldots & \ldots & \ldots & \ldots & \ldots & \ldots & \ldots & \ldots & \text { uchidai. }\end{array}$

49. Acanthodoris pilosa (ABILDGAARD, 1789)

50. Acanthodoris uchidai BABA, 1935

Subfamily Okeniinae (=Goniodoridinae)

Genus Goniodoris ForBes \& GoODSIR, 1839

Goniodoris For8Es \& G) DSIR, Athenaeum, no. 618, 1839, p. 647.

Type: Doris nodosa Montagu.

Synopsis of the Japanese species:

a. Back with a mdian longitudinal crest $\quad \ldots \quad$..

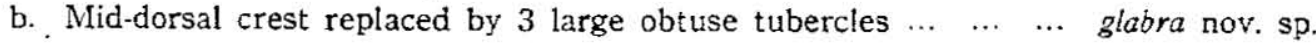

51. Goniodoris castanea ALDER \& HANCOCK, 1845

(P1. 1, fig. 5)

52. Goniodoris glabra nov. sp.

(P1. 1, fig. 6; text-fig. 2)

Distribution in Japan: Tomioka (Amakusa).

The body is limaciform and elongated, measuring about $25 \mathrm{~mm}$ in length. The back is marked off from the rest of the body by a

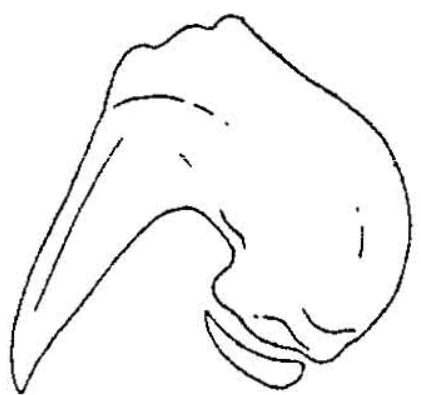

Text-fig. 2.-Goniodoris glabra. A half-row of radula $(\times 150)$. pallial flange standing recurved all around excepting at the posterior median notch. The mid-dorsal crest is replaced in this species by 3 large obtuse tubercles disposed longitudinally between rhinophores and branchiae. The rhinophore is nonretractile and has a perfoliate clavus. The tail has a mid-dorsal crest. The back and sides are covered with sparse almost indistinct tubercles. The head is produced laterally into a pair of oral tentacles. The branchiae consist of 3 non-retractile plumes arranged separately around the anus.

The general body colour is a dark chocolate sparsely spotted 
with yellow, and there is a yellow cross band a short distance behind the rhinophores.

The cuticular labial disk is without marked armatures. The radula formula is $20 \times 1.1 .0 .1 .1$. The inner lateral tooth is large, consisting of a roughly oblong base and a smooth hook without denticulations. The outer lateral tooth is simply scale-like.

Locality: Tomioka (Mar. 1934; 1 sp.).

This species is quite distinctive and differs from other members of the genus in the external form with 3 branchiae and 3 mid-dorsal tubercles, and in the inner tooth of the radula which has no denticulation. Also the coloration of this species is un. mistakable.

53. Goniodoris sp. BABA, 1935

Genus Okenia Menke, 1830

Okenia Mewre, Synops. method. Mollusc., ed. 2, 1830, p. 10.

Type: Idalia elegans LEUCKART.

With 2 subgenera: Okenia s. s. and Idaliella.

54. Okenia (Idaliella) barnardi nov. sp.

(Pl. 2, fig. 6; text-fig. 3)

Distribution in Japan: Tomioka (Amakusa).

The living animal is small, limaciform and about $10 \mathrm{~mm}$ in length. The back is marked off from the rest of the body by a low pallial ridge which bears 16 slender clavate papillae, 8 on each side, the posterior ones being bifurcated. The rhinophores are slender and non-retractile, and the greater part of their length is occupied by a perfoliate clavus. The non-retractile branchiae, 7 in number, are simply pinnate and arranged around the anus. Over the mouth is an oral veil produced laterally into a pair of tentacular expansions. The back and sides are nearly smooth; the tail is produced behind; the foot is very large and expanded. The genital orifice lies on the right side, well behind the level of the rhinophores.

The ground colour of the body is yellowish white. Inside the margin of the back there is a dark chocolate band, inclined to a brownish colour towards the centre. A similar band surrounds 
the sides of the body. The back and sides are spotted with opaque white. The rhinophores and branchial plumes are of a chocolate colour.

The labial armature takes the form of a semicircle. It consists of a large number of closely-set hooks, each bearing $5-7$ irregular

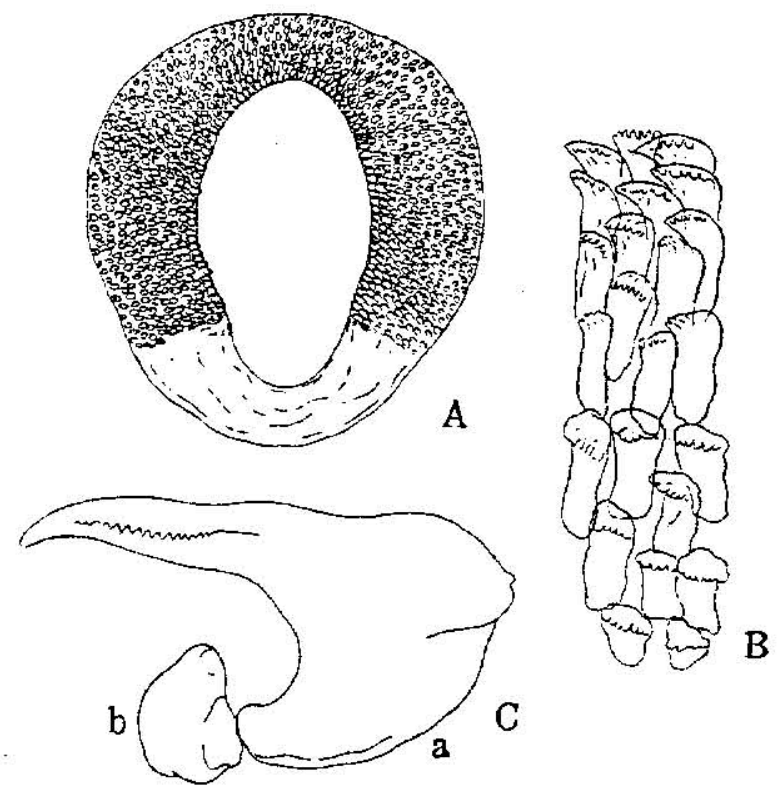

Text-fig. 3.-Okenia barnardi. A. Labial armature $(\times 90)$; B. Elements of the same $(\times 500)$; C. A row of raduia $(\times 220)$, a. inner lateral tooth, b. outer toothín.

denticles at the tip. Radula formula $22 \times 1.1 .0 .1 .1$. The inner lateral tooth is large and consists of a hook at right angles to the base; this hook bears a series of denticles about 15 in number. The outer lateral tooth is decidedly smaller and simply scale-like.

Locality: Tomioka (May 1933; 1 sp.).

The present species is referred to the subgenus Idaliella by the absence of papillae at the centre of the back, but differs from all the other species so far recorded in external features, in colours and in the shape of the labial armature. I propose to call it Okenia barnardi, after my friend Dr. K. H. BARNARD of the South African Museum, who assisted me in identifying the species.

Genus Trapania PRUVOT-FoL, 1931

Drepania LAFont, Journ. Conchyl, Paris, tom. 22, 1874, p. 369 (non Drepania HÜвNer, 1816, for Lepidoptera). 
Trapania PR!VJT.FoL, Bull. Mus. Hist. Nat. Paris, ser. 2, tom. 3, no. 3, 1931 (June), p. 309 ; Prcvin-For, ditto, no. 8, 1931, p. 747.

Drepanida MIACFarta:o, Nautilus, vol. 45, no. 1, 1931 (July), p. 31.

Type: Drepania fusca LAFonT.

5̄5. Trapania japonica (BABA, 1935) ${ }^{\mathrm{V}}$

Family Vayssiereidae ( $=$ Okadaiidae)

Genus Okadaia BABA, 1930

56. Okadaia elegans BABA, 1930

Family Dorididae

Subfamily Glossodoridinae

Genus Glossodoris EHREnBERG, 1831

Glossodoris Ehrevigerg, Symb. phys., 1831.

Chromodoris At.oer \& Hasicnck, Monogr. Brit. Nudib., pt. 7, 185.5, appendix, p. 17.

Type: Glossodoris xantholenca EHRENBERG.

Synopsis of the Japanese species:

a. First lateral tooth tricuspid, succeeding teeth bicuspid...

b. Lateral teeth very numerous (162.0.162), each with two cusps .. ... thalassopora.

c. First lateral tooth denticulate on both sides, succeeding teeth with an external denticulate margin ... ... pallescens, alderi, sibogae, aurcopurpurea, lineolata, clitonota, pantharclla.

57. Glossodoris lineolata (VAN HASSELT, 1824)

Doris lineolata vai: Hasselt, Allgem. Konst en Letter-Bode, 1824, p. 22.-Java.

Locality: Hachijô-shima (1 sp., coll. by. Mr. T. FuJITA).

58. Glossodoris festiva (ADAMS, 1861)

59. Glossodoris alderi (Collingwood, 1881) ${ }^{2}$

60. Glossodoris pallescens (BERGH, 1875)

61. Glossodoris thalassopora (BERGH, 1879)

Chromodoris thalassopora BERGH, Journ. Mus. Godeffroy, Hft. 14, 1879, pp. 19-21, pl. 4, figs. 35.40 ; pl. 5 , figs. $1.2 .-$ 'M. japonicum'.

1) Synonym: Drepania japonica, see Baвı (1935, p. 336).

2) Synonym: G. reticulata (P.Ass), see B.ins (1933, p. 169). 


\section{Glossodoris pantharella (BERGH, 1879)}

Chromodoris pantharell:z Barg:t, Journ. Mus. Godeffroy, Hft. 14, 1879, p. 3.-Formosa Strait; Bspgrt, Malakoz. Blätt., Bd. 1, 1879, pp. 94-98, pl. 3, figs. 12-25-Formosa Strait.

\section{Glossodoris aureopurpurea (CoLLINGWood, 1881)}

\section{Glossodoris clitonota (BERGH, 1905)}

Chromodoris clitonota Bễah, Siboga-Exped., 1905, p. 160, pl. 5. fig. 16.-Java; Rrsbec, Faune Colon. Franç., tom. 2, 1928, pp. 156-158; pl. 6, fig. 9, text-fig. 45.-New Caledonia.

Glossodoris clitonota TAkı, Venus, vol.3, no. 4, 1932, pp. 215-216, fig. 7.-Seto.

\section{Glossodoris sibogae (BERGH, 1905)}

Chromodoris sibogae BERGH, Siboga-Exped., 1905, p. 157, pl. 16, figs. 38-39.--Timor; Euır, Journ. Coll. Sci. Imp. Univ. Tōkyô, vol. 35, art. 1, 1913, pp. 27-28, pl. 2, fiz. 7.--Misaki ; Hiraś, Moluskoj, 1927, p. 1471, fig. 2830.-Misaki.

66. Glossodoris sp. FujITA, 1893

Chromodoris sp. Fuıtta, Dôbutsugaku Zasshi, vol. 5, no. 55, 1893, pp. 163-164, fig. 3.Misaki.

Genus Noumea Risbec, 1928

Noumea Risbec, Faune Colon. Franç., tom. 2, 1928, p. 165.

Type: Noumea romeri RISBEC.

67. Noumea nivalis nov. sp.

(Text-fig. 4)

Distribution in Japan: Seto (Kii), Zushi and Kominato.

The body is typically glossodoridiform, ranging from 8 to $15 \mathrm{~mm}$ in length. The branchiae consist of $7 \cdot 9$, small, simply pinnate plumes. No knob-like bodies are present on the postero-ventral margin of the mantle.

The ground colour of the body is snow-white. The back is ornamented with almost inconspicuous colours as follows: (1) a yellow, often discontinuous line, running all around the pallial margin; (2) a few, tiny, orange-yellow spots irregularly scattered over the centre. The upper half of the rhinophore is orangeyellow, and the basal half white. The branchial plumes are of a uniform white, sometimes tipped with yellow. The foot is without markings. 
The elements of the labial armature are closely-set tiny hooks, each with a simple or bifid tip. The radula formula is about $30 \times 25.0 .25$. The rachis is narrow, without a thickening. The 1st lateral tooth is large, consisting of an exceedingly broad base and a pointed blade. This blade bears a single denticle on the inside and $2-3$ denticles on the outside. The succeeding teeth are smaller and typically bamate, each with a series of $3-5$ denticles. The outermost teeth are also hamate, the denticles being confined to the tip of the hook.

Localities: Seto (Mar.1937; $1 \mathrm{sp}$.$) , Zushi (May 1931; 1 \mathrm{sp}$.) and Kominato (June 1933; 2 sps.).

The present species re-
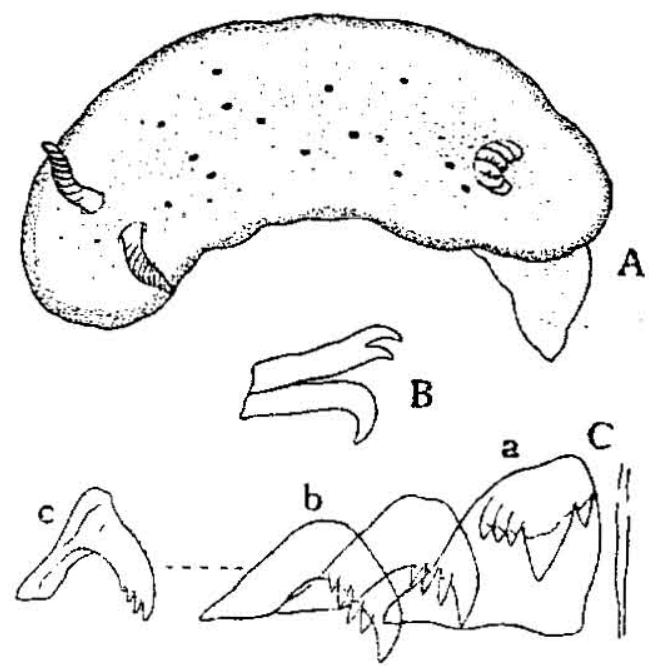

Text-fig. 4.-Noumea nivalis. A. Entire animal $(x 5)$; B. Elements of labial armature $(\times 500)$; C. A half-row of radula $(\times 500)$, a. 1st lateral tooth, b. succeeding teeth, c. outermost tooth.

sembles the New Caledonian members of Noumea in the 1st lateral tooth consisting of a large broad base, but differs in colours and in details of the radula from all of them.

\section{Genus Cadlina BERGH, 1879}

Cadlina Bepcr, Proc. Acad. Nat. Sci. Philadelphia, 1879, p. 170 (114).

Type: Doris repanda Alder \& Hancock.

Synopsis of the Japanese species:

a. Tubercles on back granular, closely set...

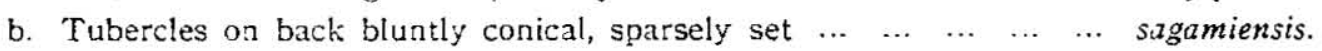

68. Cadlina japonica BABA, 1937

69. Cadlina sagamiensis BABA, 1937

70. Cadlina sp. Eliot, 1913

Cadlina (or Tyrinna) sp. Eunn, Journ. Coll. Sci. Imp. Lniv. Tôkyô, vol. 35, art. 1, 1913, p. 21.-Ago Bay. 
71. Cadlina sp. BABA, 1935

Genus Casella H. \& A. ADAMs, 1854

Casella H. \& A. Adms, Genera rec. Moll., vol. 2, 1854, p. 57.

Type: Casella gouldii H. \& A. AdAms.

\section{2.. Casella atromarginata (CUVIER, 1804)}

Doris atromarginata Cuver, Ann. Mus. Hist. Nat., tom. 4, 1804, p. 473, pl. 2, fig. 6.'Mer des Indes'.

Casella atromarginata TAkt, Venus, vol. 3, no. 4, 1932, pp. 214-215, fig. 6.-Seto.

Genus Ceratosoma ADA.MS \& ReEve, 1850

Ceratosoma Apass \& Reeve, Samarang, 1850, pp. 6i-68.

Type: Ceratosoma cornigerum ADAMS \& REEvE.

73. Ceratosoma cornigerum ADAMS \& REEvE, 1850

Subfamily Actinocyclinae

Genus Actinocyclus EHrEnberg, 1831

Actinocyclus Ehrenderg, Symb. phys., 1831.

Type: Actinocyclus verrucosus EHRENBERG.

74. Actinocyclus japonicus (ELIOT, 1913)

(PI. 1, fig. 14)

Subfamily Thorunninae

Genus Rostanga BERGH, 1879

Rostanga Bะrs,4, Arch. f. Naturgesch., Jahrg. 45, Bd. 1, 1879, p. 353.

Type: Doris coccinea ALdER \& HANCOCK.

75. Rostanga arbutus (ANGAS, 1864)

Subfamily Doridinae

Genus Echinodoris BERGH, 1874

Echinodoris Beret, Journ. Mus. Godeffroy, Hft. 6, 1874, p. 109.

Type: Doris eolida QuOY \& GAIMARD.

76. Echinodoris armata ELIOT, 1913

Echinodoris armata Eutor, Journ. Coll. Sci. Imp. Univ. Tôkyô, vol. 35, art. 1, 1913, pp. 7-8.- -Japan, 
Genus Ctenodoris Eliot, 1907

Ctenodoris Ecrut, Proc. Malac. Soc. London, vol. 7, 1907, p. 338.

Ctenodoris is especially characteristic in the transverse arrangement of the simply pinnate branchiae. These latter are retractile within a cavity, whose foremost lip is valve-like. The back is granulate. The oral tentacles are lobiform. No labial armatures. Radula formula $\infty .0 . \infty$. The lateral teeth are all hamate and smooth. The hermaphrodite gland spreads over the liver.

Type: Staurodoris pecten ElioT.

In the external configuration, Ctenodoris closely resembles Guyonia RISBEC, 1928, but the latter is said to have digitate oral tentacles, a couple of jaw-plates and a massive hermaphrodite gland separated from the liver.

\section{Ctenodoris anrantiaca (Elot, 1913) \\ (Text-fig. 5)}

Doris (Ctenodoris) aurantiaca Elıut, Journ. Coll. Sci. Imp. Univ. Tôkyô, vol 35, art. 1, 1913, pp. 5-7, pl. 1, fig. 1.-Misaki.

Distribution in Japan: Tomioka (Amakusa) and Misaki.

The body is typically doridiform and has the shape of an elongated ellipse with the mantle extending beyond the foot all around. It measures $12-26 \mathrm{~mm}$ in length. The back is closely covered with tiny obtuse granules. The branchial plumes, 14-16 in number, are simply pinnate and are arranged in a transverse row. The branchial cavity is not circular but is crescentic with the horns directed anteriorly and with the foremost valve-like lip extending behind. The oral tentacles are lobiform and contiguous at the bases. The anterior edge of the foot is abruptly truncated and bilabiate.

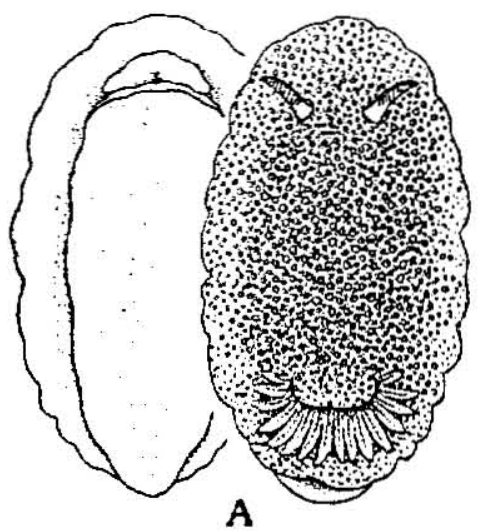

A

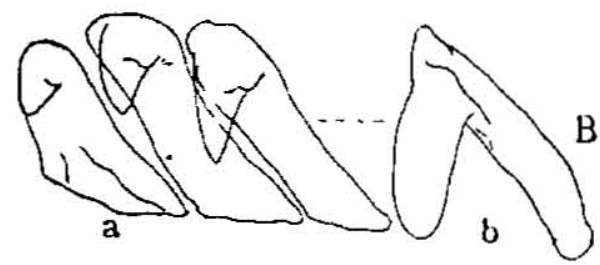

Text-fig. 5.-Cienodoris auranliaca. A. Entire animal in dorsal and ventral views $(\times 2)$; B. A half-row of radula $(\times 500), a$. innermost lateral teeth, b. outermost tooth. 
The colour of the entire animal is yellow.

The labial cuticle is without armatures. The radula formula is about $45 \times 40 \cdot 60 \cdot 0.40-60$. The lateral teeth are all simply hamate and smooth. The hermaphrodite gland covers the liver.

Locality: Tomioka (June 1535-36; 3 sps. on a yellow sponge).

\section{Subfamily Archidoridinae}

Genus Trippa Bergh, 1877

Trippa Bergi, Jahrb. Deutsch. Malakoz. Gesell., Bd. 4, 1877, p. 63; Bergh, Malac. Unters., Hft. 12, 1877, p. 543.

Type: Trippa ornata BERGH.

\section{Trippa intecta (KELAART, 1858)}

Genus Petelodoris BeRGH, 1881

Petelodoris Bergit, Verh. k. k. zool.-bot. Gesell. Wien, Bd. 31, 1881, pp. 11 (227)-12 (228).

Type: Petelodoris triphylla BERGH.

79. Petelodoris triphylla BERGH, 1881

Petelodoris triphylla BвRaH, Verh. k. k. zool.-bot. Gesell. Wien, Bd. 31, 1881, pp. 12 (228)-14 (230), pl. 7, figs. 4-15.-Enoshima.

Genus Geitodoris BERGH, 1892

Geitodoris BerGH, Zool. Jahrb., Syst., Bd. 6, 1892, p. 130.

Type: Doris complanata VerRILl.

Synopsis of the Japanese species:

a. Back grayish yellow mottled with chocolate brown. A half-row of radula composed of 3 types of teeth: inner teeth simply hamate, middle teeth hamate with a serrulated edge, outer teeth thin and crowded together ... ohshimai.

b. Back yellow. A half row of radula composed of 2 types of teeth: inner teeth simply hamate, outer teeth thin and crowded together ... ... lutca nov. sp.

80. Geitodoris ohshimai BABA, 1936

81. Geitodoris lutea nov. sp.

(Text-fig. 6)

Distribution in Japan: Tomioka (Amakusa).

The animal is doridiform and somewhat flattened, and the mantle projects beyond the foot all around. It is about $32 \mathrm{~mm}$ 
long. The back is closely covered with tiny granules. The rhinophore sheath has a granulated margin. The branchial plumes are in a circle around the anal papilla, and can be withdrawn into a cavity with a granulated margin. They number 3 on each side, with the last ones bifurcated. The oral tentacles are digitate. The foot is elongate-oval, the bilabiate front end is rounded off and the hinder end comes to a blunt point.

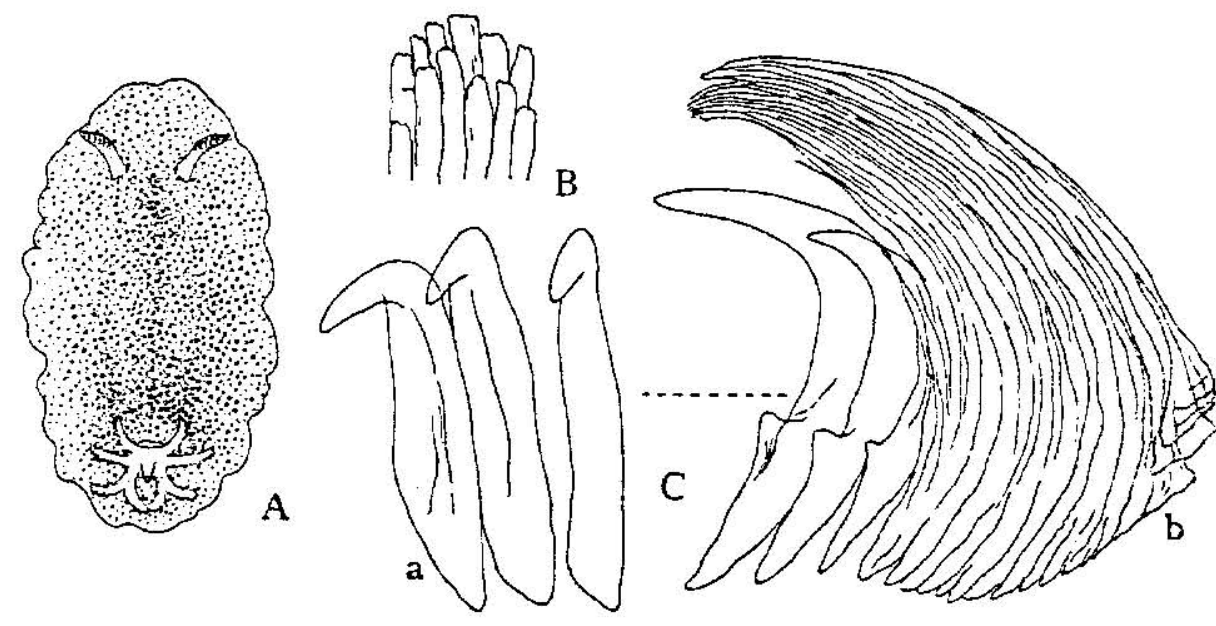

Text-fig. 6.-Geitodoris lutea. A. Entire animal in dorsal view $(\times 1.3)$; B. Elements of labial armature $(\times 380)$; C. A half-row of radula $(x 250)$, a. innermost lateral teeth, b. outermost teeth.

The general colour of the back is yellow with a dark shade towards the centre. The tips of all the granules, and the rhinophore clavi are dark brown. The under side of the body is yellow.

The labial armature is an incomplete ring, consisting of irregular rodlets closely packed together. The radula contains about 17 rows of teeth, each half-row consisting of inner and outer teeth. The inner teeth, $22-26$ in number, are simply hamate without denticles, and gradually increase in size outward. The outer teeth, about 20 in number, are spatular and closely gathered, the general appearance being thus brush-like. The hermaphrodite gland spreads over the liver.

Locality: Near Tomioka (June 1935; 2 sps.).

This species is closely allied to Geitodoris capensis BERGH in colours and radula type, but differs in having closely-set granules on the back. 


\section{Subfamily Discodoridinae}

Genus Peltodoris BERGH, 1880

Peltodoris Beren, Mittlg. Zool. Stat. Neapel, Hft. 2, 1880, pp. 223-224.

Type: Peltodoris atromaculata BERGH.

82. Peltodoris mauritiana BERGH, 1889

Genus Thordisa BERGH, 1877

Thordisa Berch, Malac. Unters., Hft. 12, 1877, p. 540.

Type: Thordisa maculigera BERGH.

83. Thordisa amakusana nov. sp.

(Pl. 1, fig. 12 ; text-fig. 7 )

Distribution in Japan: Tomioka (Amakusa).

The animal, about $30 \mathrm{~mm}$ in length, is doridiform and flattened, and has the shape of an elongated ellipse with the ends equally rounded. The mantle is soft (spicules not well developed) and wide, and the whole upper surface is closely covered with minute

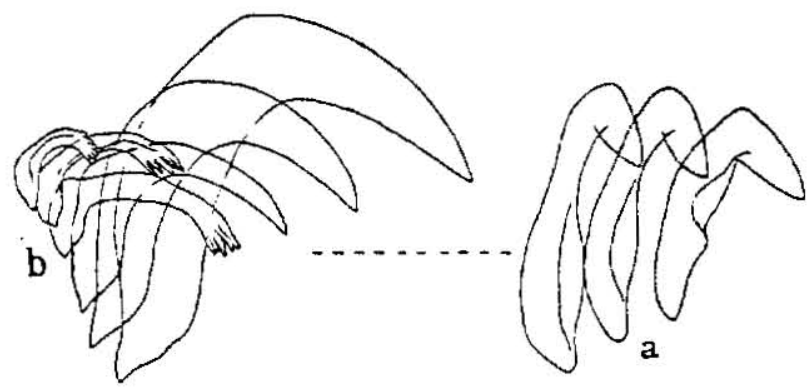

Text-fig. 7.-Thordisa amakusana. A half-row of radula $(\times 250)$, a. innermost lateral teeth, b. outermost teeth.

villous papillae. The rhinophore sheath has a smooth margin. The branchial plumes, about 12 in number, are all simply pinnate and arranged in an almost complete circle around the anus. The margin of the branchial cavity is slightly elevated and is guarded by villous papillae. The oral tentacles are digitiform. The foot is elongate-oval ; in front it is rounded off and bilabiate with a deep notch in the middle of the upper lip.

The back is orange-yellow with a dark shade over the viscera and with minute chocolate spots on the whole surface. The rhinophore clavi are chocolate and the branchiae pale orange- 
yellow; the under surface of the body is yellowish; the brim of the foot bears a series of chocolate spots.

The cuticular labial disk is without armatures. The radula formula is $20 \times 22-25.0 .22-25$. The majority of the lateral teeth are simply hamate, but the outermost $3-4$ are much reduced with split tips.

Locality: Tomioka (Mar. 1935; $1 \mathrm{sp}$.).

The present species is especially characteristic in the coloration, simply pinnate branchiae and small radula formula. In colours it recalls Thordisa hilaris BERGH, but differs mainly in the configuration of the branchiae.

\section{Genus Discodoris BerGH, 1877}

Discodoris Bєrgh, Jahrb. Deutsch. Malakoz. Gesell., Bd. 4, 1877, p. 61.

Type: Discodoris boholiensis BERGH.

Synopsis of the Japanese species:

1. Body usually large (L. $40-80 \mathrm{~mm}$ ). Radula large (40-60 laterals on each side).

a. Brown, back with large dark mottles, the darkest $(3-4)$ ones on sides $\begin{array}{llllllllllllllll}\text { of } b a c k & \ldots & \ldots & \ldots & \ldots & \ldots & \ldots & \ldots & \ldots & \ldots & \ldots & \ldots & \ldots & . . & \text { concinn } .\end{array}$

b. Yellowish brown, back with indistinct brown shades. Also back often with reticulate figures due to peculiar arrangement of various granules

2. Body usually small (L. $15.25 \mathrm{~mm}$ ). Radula small ( $14-30$ laterals on each side).

a. Branchiae 6. Back pale chocolate with dark mottles ... ... yazyamensis.

b. Branchiae 9. Ashy yellow with a few dark flecks on back... ... pallida.

84. Discodoris concinna (ALDER \& HANCOCK, 1864)

85. Discodoris pardalis (ALDER \& HANCOCK, 1864)

86. Discodoris yaeyamensis BABA, 1936

87. Discodoris pallida nov. sp.

(Pl. 1, fig. 11 ; text-fig. 8)

Distribution in Japan: Tomioka (Amakusa).

The animal in life is soft and flattened, and measures about $15 \mathrm{~mm}$ in length. The back appears almost smooth, but is actually covered everywhere with villous papillae. The rhinophore sheath has a villous margin. The tripinnate branchial plumes, about 9 in number, are small and lie in a complete circle around the anus. 
The margin of the branchial cavity is guarded by villous papillae. The oral tentacles are digitiform. The front edge of the foot is bilabiate with a deep median notch in the upper lip. Posteriorly the foot passes to a bluntly pointed tail.

The general colour of the body is an ashy yellow, becoming darker towards the median line. A small number of dark brown flecks are irregularly scattered over the back, the majority of them
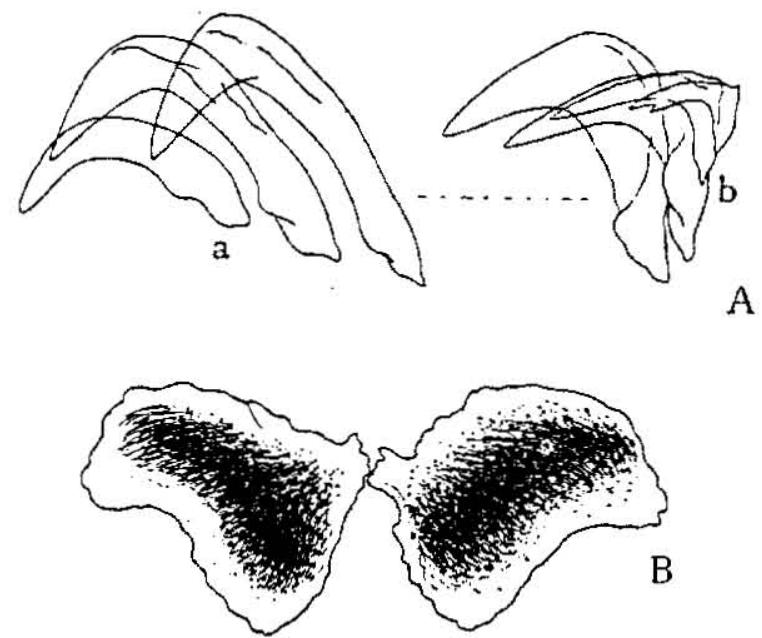

Text-fig. 8.-Discodoris pallida. A. A half-row of radula

$(\times 240)$, a. innermost lateral teeth, b. outermost teeth;

B. A pair of labial armatures $(\times 80)$.

being in the mid-dorsal region. The tips of all the papillae are dark brown. The rhinophores and branchiae are of the same colour as the mantle. The under side of the body is uniformly ashy yellow.

The cuticular labial disk is armed with a pair of roughly oblong plates, each consisting of numerous tiny rods closely packed together. The radula contains 15 rows of teeth, each half-row being composed of 14-17 lateral teeth. The 1st lateral tooth is small and simply hamate. The succeeding teeth gradually increase in size outward, and decrease again to the edge. The outermost tooth is usually simple, sometimes split at the tip.

Locality: Tomioka (Oct. 1935; 1 sp.).

The present species closely resembles the Californian form Discodoris heathi MACFARLAND in colours, but differs from it in the type of the radula. In the latter species the radula is broad 
with the formula $20 \times 36-42.0 .36-42$, each half-row falling in two groups of different types.

Subfamily Homoeodoridinae

Genus Homoeodoris BERGH, 1881

Homoiodoris Bergh, Verh. k. k. zool.-bot. Gesell. Wien, Bd. 31, 1881, pp. $6(222) \cdot 7$ (223).

Homoeodoris Threle, Handb. syst. Weicht., Th. 2, 1931, p. 438.

Type: Homoeodoris japonica BERGH.

88. Homoeodoris japonica BERGH, 1881

Subfamily Asteronotinae

Genus Halgerda BERGH, 1880

Halgerda Bergf, Verh. k. k. zool.bot. Gesell. Wien, Bd. 30 , 1880, p. 38 (190).

Type: Halgerda formosa BERGH.

Synopsis of the Japanese species:

a. Back with prominent subconical tubercles interlinked by low ridges ... graphica.

b. Back covered with fine villous papillae $\begin{array}{llllllllll}\ldots & \ldots & \ldots & \ldots & \ldots & \ldots & \ldots & \ldots & \text { japonica. }\end{array}$

89. Halgerda graphica BASEDOW \& HEDLEY, 1905

90. Halgerda japonica ELIOT, 1913

Genus Asteronotus EHRENBERg, 1831

Asteronotus Ehrenberg, Symb. phys., 1831.

Type: Asteronotus hemprichii EHRENBERG.

91. Asteronotus cespitosus (van Hasselt, 1824)

Subfamily Arginae (=Platydoridinae)

Genus Argus BoHADSCH, 1761

Argus Bonadсr, Anim. mar., 1761, p. 65.

Platydoris Bsrgh, Jahrb. Deutsch. Malakoz. Gesell., Bd. 4, 1877, p. 73.

Type: Argus argo BoHadsch.

Synopsis of the Japanese species:

A. Body large (L. $60-90 \mathrm{~mm}$ ). Radula large (90-150 laterals on each side).

1. Back with cloudy chocolate figures, under side orange-yellow with oral $\begin{array}{llllllllllll}\text { chocolate markings } & \ldots & \ldots & \ldots & \ldots & \ldots & \ldots & \ldots & \ldots & \ldots & \ldots & \text { speciosus. }\end{array}$ 


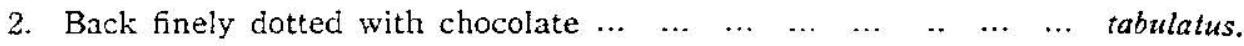

3. Back with wavy chocolate lines.

a. Crimson blotches on back and under side $\ldots \begin{array}{lllll}\ldots & \ldots & \ldots & \ldots & \text { cruentus. }\end{array}$

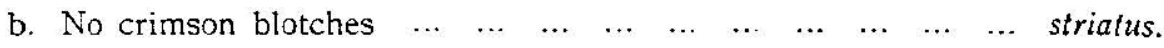

B. Body small (L. $25 \mathrm{~mm}$ ). Radula small (50 laterals on each side). Yellowish, with chozolate mottles on back, mantle and branchial cavity margined $\begin{array}{lllllllllllllll}\text { with yellow } & \ldots & \ldots & \ldots & \ldots & \ldots & \ldots & \ldots & \ldots & \ldots & \ldots & \ldots & \ldots & \ldots & \text { esakii. }\end{array}$

\section{Argus cruentus (QUOY \& GaIMARD, 1832)}

93. Argus striatus (KelaART, 1858)

Doris striata Kelankt, Journ. Asiatic Soc. Colombo, vol. 3, pt. 1, 1858.

Platydoris striata Eltor, Journ. Coll. Sci. Imp. Univ. Tôkyô, vol. 35, art. 1, 1913, pp. 1820.- Kataura.

\section{Argus speciosus (ABRAHAM, 1877) \\ 95. Argus tabulatus (ABraham, 1877) \\ 96. Argus esakii BABA, 1936 \\ Genus Doriopsis Pease, 1860}

Doriopsis Pease, Proc. Zool. Soc. London, 1860, p. 32.

Guyonia Risbec, Faune Colon. Franç., tom. 2, 1928, p. 102.

Type: Doriopsis granulosa PEASE.

\section{Doriopsis viridis Pease, 1861}

Doriopsis viridis Pease, Proz. Zool. Soz. London, 1851, pp. 244-245.-Tahiti.

Doris pecten Crlingwood, Trans. Linn. Soc. London, Zool., vol. 2, 1881, p. 126, pl. 9 , figs. 1-5. -Bush Island (Keelung).

\section{Subfamily Dendrodoridinae (=Doridopsinae) \\ Genus Dendrodoris EHRENBERG, 1831}

Dendrodoris EHREN BERG, Symb. phys., 1831.

Doriopsis Bergit, Journ. Mus. Godeffroy, Hft. 8, 1875, pp. 82.87 .

Doridopsis Atuer \& Hancock, Trans. Zool. Soc. London, vol. 5, pt. 3, 1864, pp. 124-126.

Type: Dendrodoris lugubris EHRENBERG.

With two subgenera: Dendrodoris s. s. and Doriopsilla.

Synopsis of the Japanese species:

A. Body very soft (Dendrodoris s. s.).

1. Back entirely smooth.

a. Colours variable, usually black nigra. 
b. Yellow or orange yellow, the back with black irregular mottles $\begin{array}{llllllllll}\ldots & \ldots & \ldots & \ldots & \ldots & \ldots & \ldots & \ldots & \ldots & \text { rubra } \text { var. nigromaculata. }\end{array}$

c. Orange-yellow, the back with small, black, well defined mottles $\begin{array}{llllllllllllll}\ldots & \ldots & \ldots & \ldots & \ldots & \ldots & \ldots & \ldots & \ldots & \ldots & \ldots & \ldots & \ldots & \text { guttala. }\end{array}$

2. Back sparsely granulate. Body exceedingly elongated. Dirty yellow, mottled $\begin{array}{lllllllllllll}\text { with } \text { dark brown } & \ldots & \ldots & \ldots & \ldots & \ldots & \ldots & \ldots & \ldots & \ldots & \ldots & \ldots & \text { elongata. }\end{array}$

3. Back with warty compound protuberances.

a. Back dirty yellow with a large dark brown network ... tuberculosa var.

b. Back yellowish white with 3 longitudinal rows of dark brown areas, each

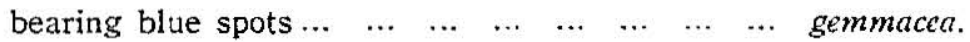

B. Body spiculate, rather rigid (Doriopsilla). Orange-yellow, the back with a whitish $\begin{array}{lllllllllllllll}\text { network } & \ldots & \ldots & \ldots & \ldots & \ldots & \ldots & \ldots & \ldots & \ldots & \ldots & \ldots & \ldots & \ldots & \text { miniata. }\end{array}$

98. Dendrodoris (Dendrodoris) tuberculosa (QUOY \& GAIMARD, 1832), variety

99. Dendrodoris (Dendrodoris) nigra (STIMPson, 1855) ${ }^{1}$

100. Dendrodoris (Dendrodoris) gemmacea (ALDER \& HANCOCK, 1864)

(P1. 1, fig. 4)

101. Dendrodoris (Dendrodoris) mbra var. nigromaculata (ELIOT, 1913)

102. Dèndrodoris (Dendrodoris) guttata (ODHNER, 1917)

(P1. 1. fig. 13)

103. Dendrodoris (Dendrodoris) elongata BABA, 1936

104. Dendrodoris (Doriopsilla) miniata (ALDER \& HANCOCK, 1864) (Pl. 1, fig. 1)

Family Phyllididae

Genus Phyllidia Cuvier, 1796

Phyllidia Cưver, Bull. Sci. Soc. Philom. Paris, 1796, p. 105.

Type: Phyllidia varicosa LAMARCK.

With 4 subgenera: Phyllidia s. s., Phyllidiella, Phyllidiopsis, and Ceratophyllidia.

Synopsis of the Japanese species:

a. Warts on back fused into (3) longitudinal and (many) short marginal ridges $\begin{array}{llllllllll}\ldots & \ldots & \ldots & \ldots & \ldots & \ldots & \ldots & \ldots & \ldots & \text { varicos } a\end{array}$

1) Synonym: D. nigra variety, see $B_{A B A}(1935)$, p. 348 . 


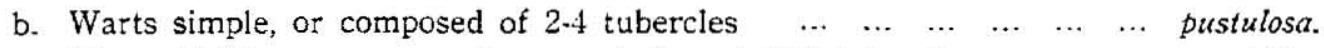

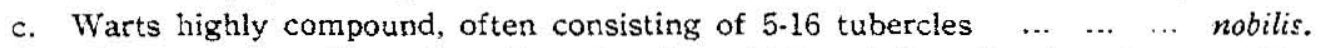

d. Warts mostly solitary but those in the mid-dorsal line fused to form a ridge $\begin{array}{lllllllllll}\ldots & \ldots & \ldots & \ldots & \ldots & \ldots & \ldots & \ldots & \ldots & \text { japonica } \text { nom. nov. }\end{array}$

105. Phyllidia (Phyllidia) varicosa LAMARCK, 1801

106. Phyllidia (Phyllidiella) pustulosa Cuvier, 1804

107. Phyllidia (Phyllidiella) nobilis (BERGH, 1869)

108. Phyllidia (Phyllidiella) japonica nom. nov.

Pinyllidia tuberculata BABA, Venus, vol. 2, no. 3, 1930, pp. 117.118, pl. 4, fig. 1.-Tateyama Bay.

In 1930 Phyllidia tuberculata was proposed as a new species. But as the specific name tuberculata is already preoccupied by $P$. tuberculata RisBeC ${ }^{1)}$, I must rename the present species $P$. japonica nom. nov.

\section{Tribe. 2. Cladohepatica (=Aeolidiacea)}

Family Duvauceliidae

Genus Duvaucelia Risso, 1826

Duvaucelia Risso, Hist. nat. Europe mérid., 4, 1826, p. 38.

Type: Duvaucelia gracilis RIsso.

With 5 subgenera: Duvaucelia s. s., Candellista, Microlophus, Tritonidoxa and Sphaerostoma.

Synopsis of the Japanese species:

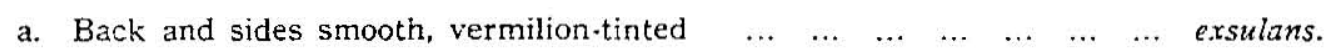

b. Back with traces of tubercles, sides smooth, whitish reticulation on back $\begin{array}{llllllllll}\ldots & \ldots & \ldots & \ldots & \ldots & \ldots & \ldots & \ldots & \ldots & \text { reticulata. }\end{array}$

109. Duvaucelia (Duvaucelia) reticulata (BERGH, 1881)

Tritonia reticulata BERGk, Verh. k. k. zool.-bot. Gesell. Wien, Bd. 31, 1881, pp. 23 (239)-

34 (250), pl. 8, figs. 7.20 ; pl. 9, figs. 1.12 ; pl. 10, figs. 1-10.-'M. japonicum'.

110. Duvaucelia (Duvaucelia) exsulans (BERGH, 1894)

(Text-fig. 9)

Tritonia exsulans Bergn, Bull. Mus. Comp. Zool. Harvard, vol. 25, no. 10, 1894, pp. $150-152$, pl. 3 , figs. 11.12 ; pl. 4, fig. 6.-Off California; O'D wogue, Trans.

1) Risвес (1928), p. 59 . 
Roy. Canad. Inst., vol. 13, pt. 1, 1921, pp. 152-154, p1. 7, figs. 4-6.-near Departure Bay.

Distribution in Japan: Sakhalin.

The animal is about $75 \mathrm{~mm}$ long. The frontal veil is expanded with a median notch, and bears on each side a series of 6.7 small conical papillae and on the ventral side a spoon-shaped, grooved tentacle at the lateral edge. The rhinophore sheath is elevated with an upper crenulate margin. The back is sharply marked off from sides by dorso-lateral ridges, each bearing $15-16$ branchial tufts. The anal papilla lies about half way back on the right side of the body between the branchial tufts, 6 and 7 ; the genital
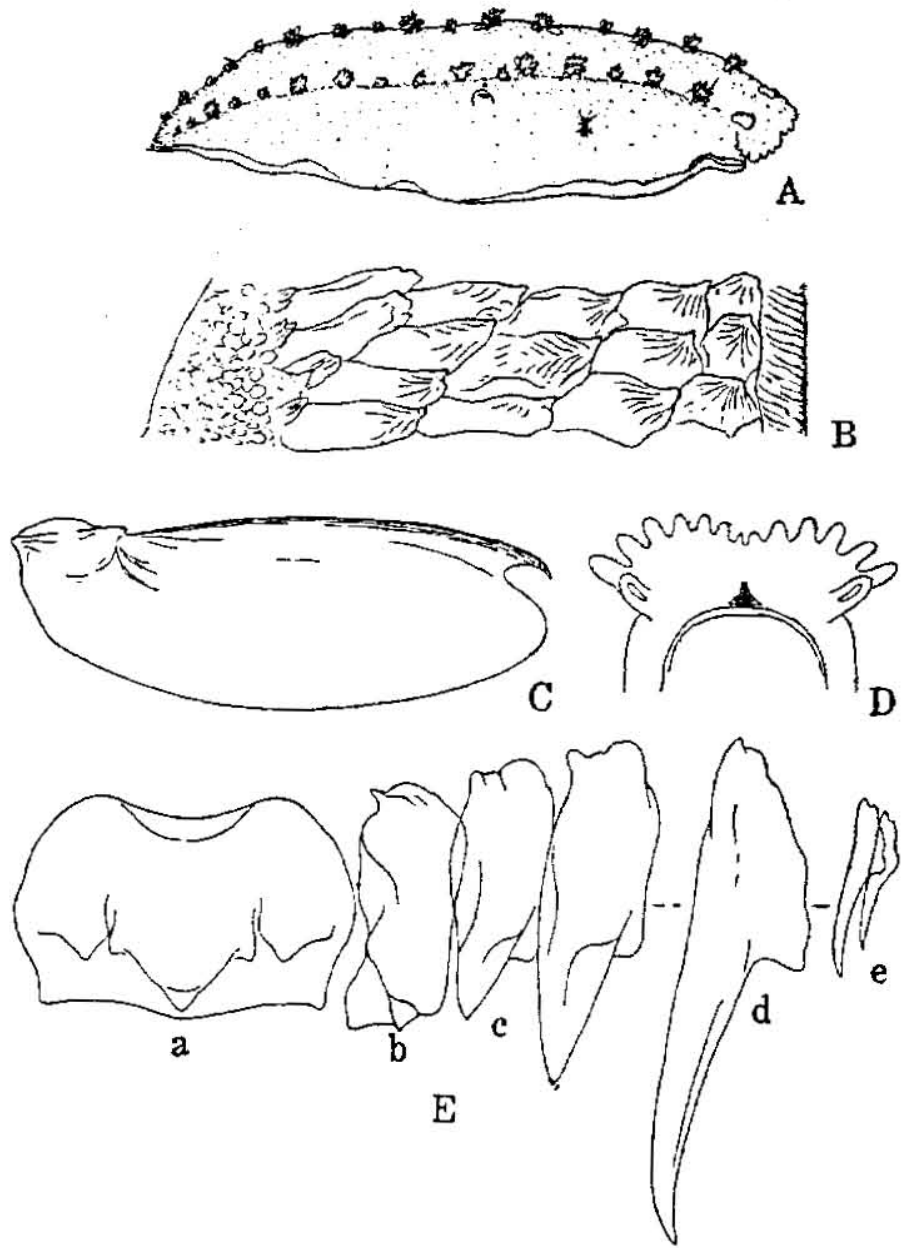

Text-fig. 9.-Duvaucelia exsulans. A. Entire animal in lateral view $(\times 0.8)$; B. Masticatory edge of jaw-plate $(\times 90)$; $C$. Jaw-plate $(\times 2)$; D. Mouth parts $(\times 1.3)$; E. A half-row of radula $(\times 70)$, a. central tooth, b. 1st lateral tooth, $c$. 2nd tooth, d. 40th tooth, e. outermost teeth. 
orifice is situated a short distance in front of the anus, beneath the 4th tuft. The nephroproct opens immediately above the anus. The back and sides appear to be quite smooth. The anterior end of the foot is abruptly rounded and bilabiate.

According to Mr. URITA the living animal was vermilion-tinted with whitish branchial tufts.

The masticatory process of the jaw-plate has several rows of imbricating scales. The radula formula is $65 \times 75-95.1 .1 .1 .75-95$. The central tooth is broad and tricuspid. The 1st lateral tooth is clumsy with a small blunt spine, and is followed by a series of hamate lateral teeth reaching a maximum near the middle of the row. The liver is a large mass covered partially by the hermaphrodite gland. There are no stomachal plates.

Locality: Sakhalin (1 sp., coll. by Mr. T. URITA).

Genus Tritoniopsilla Pruvot-For, 1933

Tritoniopsilla PRUvor-For, Mém. Inst. Egypte, tom. 21, 1933, p. 108.

Type: Tritoniopsis brucei ElIOT.

111. Tritoniopsilla tetraquetra (PALLAS, 1788) ${ }^{1)}$

Limax tetraquetra PaLiss, Nova Acta Petropolit., vol. 2, 1788, pp. 237, 239, pl. 5, fig. 22. - 'Mari Kurilas'.

Tritonia tetraquetra Beran, Proc. Acad. Nat. Sci. Philadelphia, 1879, pp. 154 (98)-161 (105), pl. 3, figs. $13-16$; pl. 4, figs. 5.12; pl. 5, figs. 1-2.- Insulae Kurilae, Aleutianae'.

Genus Marionia VAYSSIÈRE, 1877

Marionia Vayssıtere, Anın. Mag. Nat. Hist., ser. 4, vol. 20, 1877, pp. 367-368.

Type: Marionia berghi VAYSSIÈRE.

Synopsis of the Japanese species:

a. Back without distinct polygons but with warts. Radula formula $38 \times 50.1 .1 .1 .50$; masticatory process of jaw-plate with 4.5 rows of denticles ... ... granularis.

b. Back with polygons and warts. Radula formula $52.70 \times 1 \% 5 \cdot 130.1 .1 .1 .125-130$; masticatory process covered partially with irregular rudimentary armatures $\begin{array}{llllllllll}\ldots & \ldots & \ldots & \ldots & \ldots & \ldots & \ldots & \ldots & \ldots & \text { pustulosa odhneri nov. subsp. }\end{array}$

112. Marionia granularis ODHNER, 1936

Marionia granularis Odnner, Mém. Mus. Roy. Hist. Nat. Belgique, ser. 2, fasc. 3, 1936, p. 109), pl., fig. 6 ; text.fig. 21.-Formosa Channel $\left(20^{\circ} 20^{\prime}\right.$ N., $121^{2} 30^{\prime}$ E.).

1) See Oorner (1936), p. 1080. 
113. Marionia pustulosa odhneri nov. subsp.

(Text-figs. 10.11)

Distribution in Japan: Momotori near Toba.

Several living specimens ranging from 40 to $80 \mathrm{~mm}$ in length. The frontal veil is two-lobed with a slight median notch, and bears on each side 8.10 small conical papillae and at its postero-lateral edge a grooved spoon-shaped tentacle. These papillae have each 1-3 accessory knobs mainly on the ventral side. The margin of the rhinophore sheath is crenulate. From 10 to 12 large branchial tufts are present on dorso-lateral ridges, each with a short stalk. The anal papilla lies on the right of the body between the branchial tufts 4 and 5 , or 5 and 6 ; the genital orifice is situated beneath the 3 rd or 4 th tuft. The position of the nephroproct
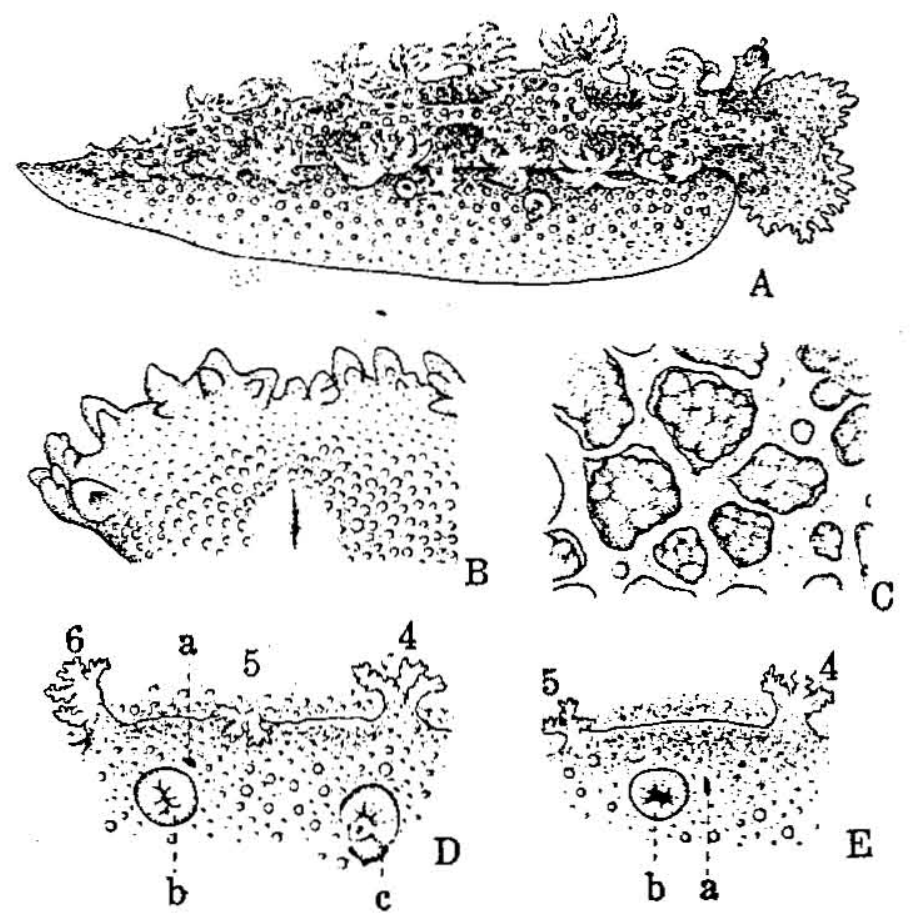

Text-fig. 10.-Marionia pustulosa cdhneri. A. Entire animal in lateral view $(\times 1)$; B. Ventral view of head-veil; C. Polygons and warts of back; D.E. Right side of body to show local relations among anus, nephroproct and genital orifice, a. nephroproct, b. anus, c. genital orifice.

differs in different individuals. In some specimens this opening is found above and in front of, and in others just in front of, the anus. The whole upper surface of the body (back, sides, frontal veil, 
branchial stalks and rhinophore sheaths) is closely covered with granular tubercles which are apt to fuse into compound warts on the back and sides. Dorsally the warts and tubercles are interlined with the so-called indistinct polygons.

The back and frontal veil are olive green covered with a fine purple reticulation. In addition there is a pale broad median band from the head to the tip of the tail, sending off similar lateral bands to the bases of the branchial tufts. The sides of the body and the foot are olive green. .

The jaw-plate has a smooth cutting edge. The surface of the

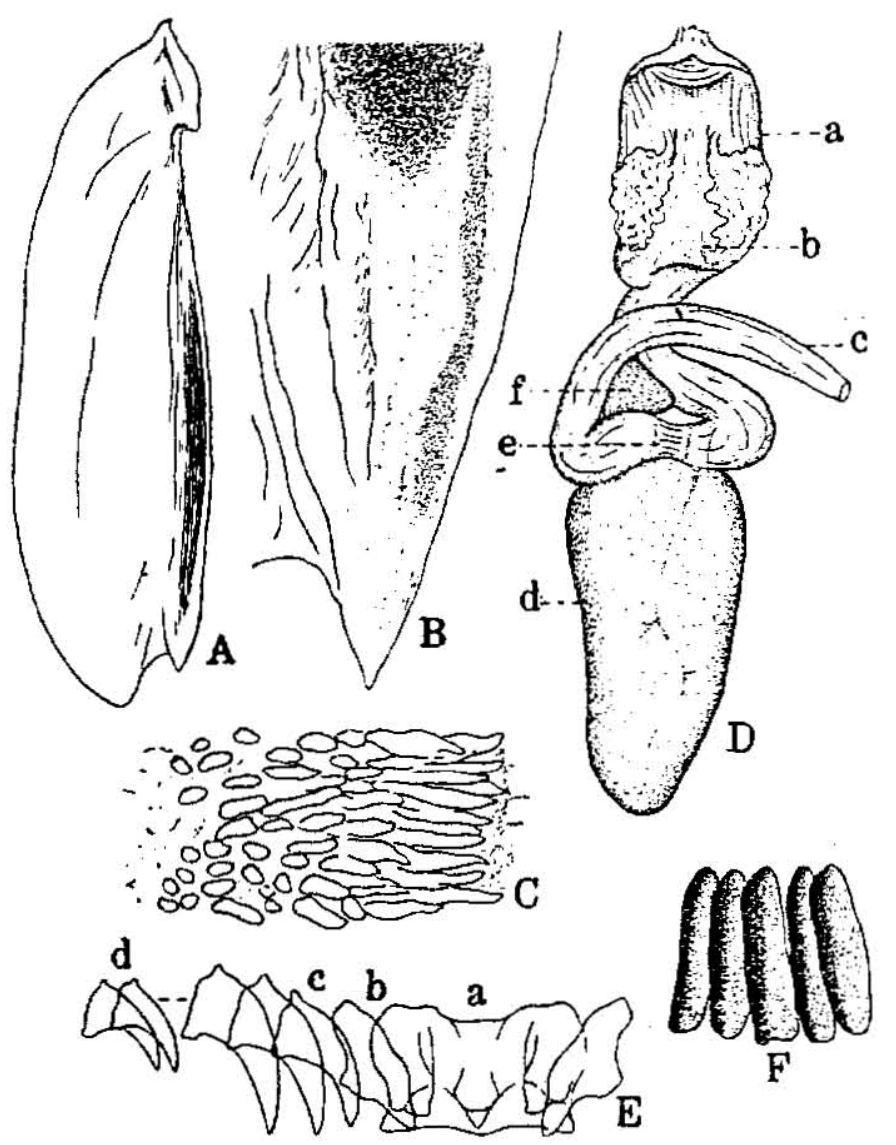

Text-fig. 11.-Marionia pustulosa odhneri. A. Jaw-plate $(\times 3)$; B. Masticatory process $(\times 30)$; C. Scales on masticatory process $(x 300)$; D. General aspect of diges. tive organs, a. pharyngeal bulb, b. oesophagus, c. intestine, d. posterior liver, e. stomach, f. anterior liver; E. A half-row of radula ( $\times 70$; a. central tooth, b. Ist lateral tooth, c. succeeding teeth, d. outermost teeth; F. Stomachal plates $(\times 10)$. 
masticatory process appears to be almost even, but a closer examination reveals that it is partially covered with irregular, almost rudimentary armatures, the outermost being spiny and the rest scale-like. The radulae in two specimens dissected contain 52-70 rows of teeth, each half-row consisting of exceedingly numerous (125-130) lateral teeth. The central tooth consist of an approximately rectangular plate bearing 3 large cusps, of which the median is the largest. The 1st lateral tooth differs in form from the succeeding teeth which are all simply hamate without denticles. The stomach is armed with a girdle of about 28 hornyellow plates. The liver consists of a small anterior and a large posterior lobe.

Locality: Momotori near Toba (July 1931; fairly common).

The present form agrees quite well with the Queensland species, Marionia pustulosa ODHNER, in all the essential characters (general external aspects, type of jaws and radula), but differs slightly in the possession of well-developed stomachal plates, having rhinophore sheaths with a crenulate edge and smaller dorsal polygons. It is recorded here as a subspecies (or variety?) of the above-said species, under the name $M$. pustulosa odhneri nov. subsp.

Genus Marioniopsis OdHNER, 1934

Marioniopsis OdH:ER, "Terra Nova" Exped., Zool., vol. 7, no. 5, 1934, p. 286.

Type: Tritonia cyanobranchiata RüPPELL \& LELCKART.

\section{Marioniopsis ? babai ODHNER, 1936}

Dievaucelia irrorata BABA, Annot. Zool. Japon., vol. 14, no. 2, 1933, pp. 274-275, fig. 1. -Tomioka.

Marioniopsis babai Odiner, Mém. Mus. Roy. Hist. Nat. Belgique, ser. 2, fasc. 3, 1936, p. $1085,1087$.

The main characters are those previously given, to which may be added: on each latero-ventral edge of the frontal veil is borne a grooved spoon-like tentacle; the genital orifice lies on the right body side below the 2nd, and the anus below the 4 th branchial tuft; the inner wall of the stomach is armed with a girdle of whitish chitinous plates.

As is suggested by Dr. ODHNER, a further study on jaws and liver system is needed before the present form is satisfactorily placed within the genus Marioniopsis. 


\section{Family Arminidae (=Pleurophyllidiidae) \\ Subfamily Dermatobranchinae}

Genus Dermatobranchus van Hasselt, 1824

Dermatobranchus vas: Hasjer. , Allgem. Konst en Letter-Bode, 1824, p. 37.

Pleuroleura Bergh, Malac. Unters., Hft. 6, 1874, p. 277.

\section{Type: Dermatobranchus striatus vaN HasselT.}

\section{Dermatobrachus striatus VAN HASSELT, 1824}

(P1. 2, fig. 1 ; text-fig. 12)

Dermatobranchus striatus vax Hassfit, Allgem. Konst en Letter-Bode, 182 4 , pp. 37-38. -Java; Bergh, Notes Leyden Mus., vol. 9, 1887, pp.311-312, pl. 6, figs. 1-2. Pleuroleura striata Beron, Zoo!. Jahrb., Syt., Bd. 3, 1888, p. 362; Elrot, Journ. Coll. Sci. Imp. Univ. Tôkyô, vol. 35, art. 1, 1913, pp. 41-42.-Misaki.

Distribution in Japan: Tomioka (Amakusa), Seto (Kii), Misaki and Tateyama.

The animal measures $20-30 \mathrm{~mm}$ in length. The head is expanded in a smooth semicircular veil, behind which is a sort of neck bearing a pair of approximating rhinophores. It continues
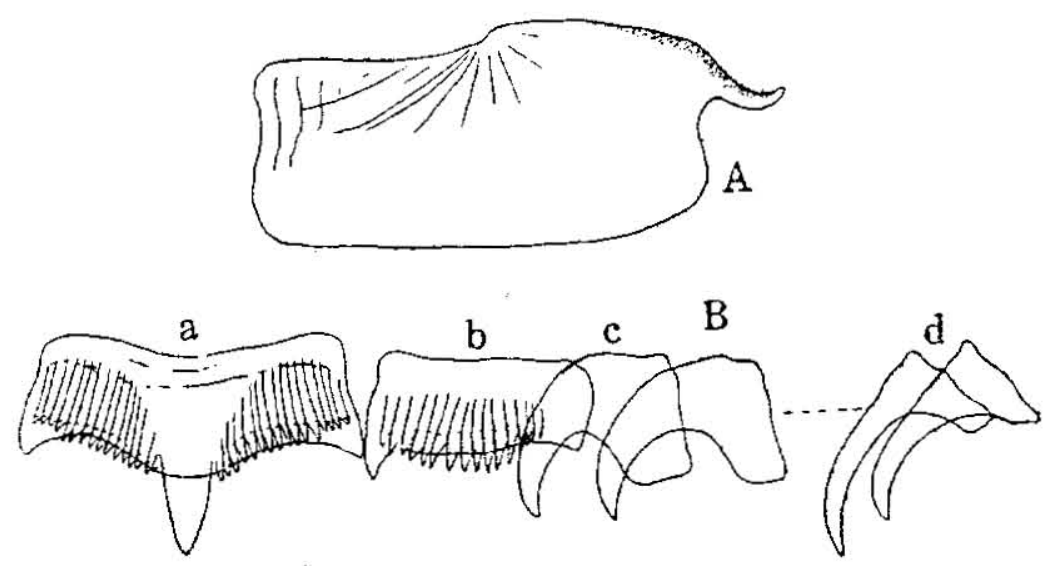

Text-fig. 12.-Dermatobranchus striatus. A. Jaw-plate $(\times 50)$; B. A half-row of radula $(\times 470)$, a. central tooth, b. 1st lateral tooth. c. 2nd tooth, d. outermost teeth.

back into a tongue-shaped mantle without line of demarcation. The rhinophore is a non-retractile cylindrical structure with a longitudinally perfoliate clavus. Dorsally the mantle is marked with (about 18) low longitudinal ridges, while on the lower extreme margin there is a series of cnidophores. The sides of 
the body are quite smooth and are free from branchial ridges. The genital orifice lies on the right body side immediately behind the head-veil. The anus opens a short distance behind the genital orifice. The foot is lanceolate, often extending beyond the mantle all around. The front end is broad and continued out laterally into slight obtuse expansions. A median longitudinal furrow runs down on the posterior two-thirds of the pedal sole.

The ground-colour of the body is a fleshy white. The back is marked with fine, dark, continuous or discontinuous lines running along the grooves among the longitudinal ridges; with irregularly scattered black dots defined by pale chocolate ocelli; with a dark semilunar band across the level of the anus. The upper half of the rhinophore is vivid orange, and the lower half white. The head-veil, sides, and foot are of a uniform fleshy white without markings.

The jaw-plate has a produced, horn-like masticatory process, and the edge is armed with several rows of spiny denticles. The radula formulae in two specimens are $30 \times 15.1 .1 .1 .15$, and $34 \times$ 10-13.1.1.1.10-13. The central tooth is wide with a series (13-17) of denticles on either side of a large median cusp. The 1st lateral tooth is like a half of the central tooth, bearing 15-17 denticles. The succeeding teeth are all simply hamate without denticles.

Localities: Tomioka (Feb. 1935; 2 sps.), Seto (Mar. 1937; 1 sp.) and Tateyama (May 1929; several sps.).

The present species is distinguished from the other members of Dermatobranchus mainly by the folded mantle, peculiar coloration and type of the radula.

\section{Subfamily Armininae}

\section{Genus Armina Rafinesque, 1814}

Armina Rafinesque, Précis découv. somiol., 1814, p. 30.

Pleurophyllidia Mecket, Meckins Deutsch. Arch. Physiol., Bd. 8, 1823, p. 197.

Type: Armina tigrina RAFINESQUE.

With 3 subgenera, viz., Armina s. s., Linguella and Camarga.

Synopsis of the Japanese speries:

I. Head-veil.separated from mantle by a clear boundary; rhinophores close together (Armina s. s.). 
A. Head-veil papillated.

a. Papillae few (11-14); a single side-lamella on each side ... comta.

b. Papillae many (50.80); side-lamellae $4-7$ on each side ... papillata.

B. Head-veil smooth.

1. Side-lamellae few, in longitudinal rows.

a. Number of lateral teeth moderate $(40-50)$; 1 st and succeeding inner teeth denticulate; side-lamellae $3-5$ on each side ... ... japorica.

b. Number of lateral teeth exceedingly large (231); 1st lateral tooth denticulate, succeeding teeth smooth; side-lamellae 8 on each

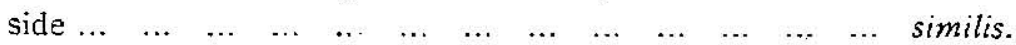

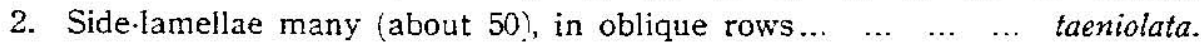

II. No clear boundary between head-veil and mantle; rhinophores widely separated (Linguella).

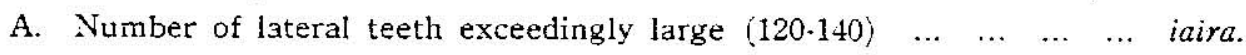

B. Number of lateral teeth moderate (22.50).

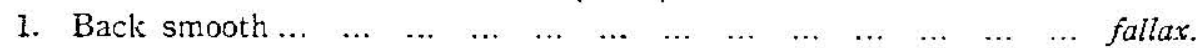

2. Back granulated.

a. Mantle-flange with two colossal appendages $\quad \ldots \quad \ldots \quad \ldots$ variolosa.

b. Mantle-flange without appendages...

\section{Armina (Armina) taeniolata (BERGH, 1866)}

(Text-fig. 13)

Pleurophyilidia taeniolata Beron, Naturh. Tidsskr., ser. 3, vol. 4, 18E6, pp. 42.46, pl. 5, figs. 1.22 ; pl. 6, figs. 1-9.-Mozambique; Etıor, Journ. Conch., London, vol. 11, no. 8, 1905, pp. 239-240, pl. 5, fig. 1.-Maskat; Euror, Proc. Zool. Soc. London, 1906, pt. 2, pp. 679-680.-India.

\section{Distribution in Japan: Kii and Tateyama.}

The animal, preserved, measures about $60 \mathrm{~mm}$ in length. The head veil is smooth above. It is marked off from the mantle by a clear boundary. The rhinophores lie close together as usual. Dorsally the mantle is marked with (about 30-35) longitudinal ridges. The anterior gills consist of delicate longitudinal folds, some of which are continuous behind with the side-lamellae. These latter are in the form of many (about 50) short ridges arranged in oblique rows and extending from the anterior gill-folds to the posterior end of the mantle. The genital orifice opens on the right side below the anterior gill-folds. The anus is situated about half way back on the same side. The nephroproct lies about midway between genital orifice and anus. The foot has a median ventral furrow.

According to a coloured sketch by Mr. OKamoto, the headshield is black bordered with yellow; the upper side of the mantle 
is black ornamented with many whitish longitudinal lines (ridges) and a yellow border; the under side of the mantle and the sidelamellae are brown; the foot is purplish black.
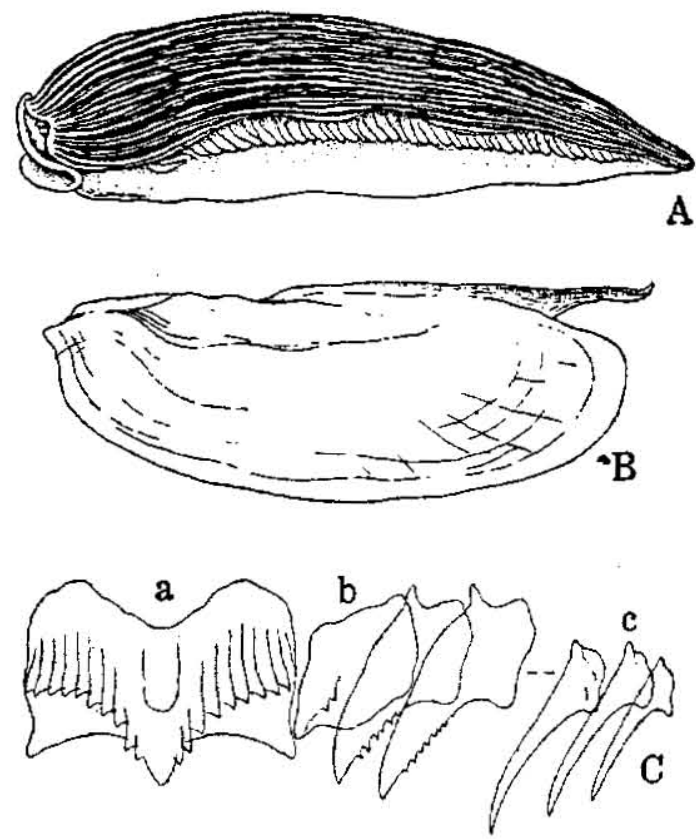

Text.fig. 13.-Armina takniolata. A. Lateral view of entire animal $(\times 1)$; B. Jaw-plate $(\times 6)$; C. A half-row of raduia $(\times 90)$, a. central tooth, b. 1st lateral tooth, c. outermost teeth.

The masticatory edge of the jaw-plate is covered with several rows of scale-like armatures. The radula formula for the Kii specimen is about $35 \times 55.1 .1 .1 .55$. The central tooth is broad with about 9 denticles on each side of a large median cusp. The 1st lateral tooth has a rectangular base, which gives off an inner claw-like spine and bears a few (1-2) denticles (or sometimes these are missing altogether). The succeeding teeth excepting several (20) outermost are all hamate with a few (5-8), indistinct denticles.

The radula formula for the Tateyama specimen is about $55 \times$ 45.1.1.1.45. The central tooth is broad with 5-6 denticles on each side of a median spine. The 1st lateral tooth differs in form from the succeeding teeth. All the lateral teeth are without denticles.

Localities: Kii (May 1933; 1 sp. coll. by Mr. K. Окамото) and Tateyama (1 sp). 
The above description agrees well with those given by BERGH and ELIOT for Pleurophyllidia taeniolata. This species appears to be especially characteristic in the oblique arrangement of the side-lamellae and in the type of the radula.

117. Armina (Armina) comta (BERGH, 1880)

118. Armina (Armina) japonica (Elıot, 1913)

119. Armina (Armina) similis (ELror, 1913)

Fleurophyllidia similis EŁıั, Journ. Coll. Sci. Imp. Univ. Tôkyô, vol. 35, art. 1, 1913, pp. 39.40.-Misaki.

120. Armina (Armina) papillata (BABA, 1933)

121. Armina (Linguella) iaira (BERGH, 1865)

Sancara iaira BERGH, Vidensk. Meddel. Naturh. Foren., (1864), 1865, pp. 178-194, pi. 3 ; BErgit, Naturh. Tidsskr., ser. 3, vol. 4, 1866, pp. 64-68.-Japan.

Linguella iaira Berci, Malac. Unters., Hft. 6, 1874, p. 268, pl. 34, figs. 25.26.

122. Armina (Linguella) fallax (BERGH, 1880)

Linguella fallax B£RGH, Verh. k. k. zool.bot. Gesell. Wien, Bd. 30, 1880, pp. 25 (177)28 (18) ), pl. 2, figs. $13 \cdot 15$; pl. 3 , fig. 13 ; pl. 4, figs. 4-7.-Enoshima.

123. Armina (Linguella) variolosa (BERGH, 1904)

Linguella variclosa Berah, Semprer's Reisen, Bd. 9, Th.6, Lief. 1, j904, pp. 21-24.Tonsang Harbour (China); Elift, Journ. Coll. Sci. Imp. Univ. Tôkyô, vol. 35, art. 1, 1913, pp. 40.41.-Minatomura.

124. Armina (Linguella) babai (TCHANG, 1936)

Linguella babai Teranc, Contrib. Inst. Zool. Nat. Acad. Peiping, vol. 2, no. 2, 1936, pp. $100-120$, $146-147$, figs. $47-55$; pl. 2 , figs. $7 \cdot 10$; pl. 3 , fig. 12 ; pl. 15.-Tsingtao.

Lacality: Momotori near Toba (July 1931; 3 sps.).

Family Dironidae

Genus Dirona Cockerell \& Eliot, 1905

Dirona Cickerell \& Eliot, Journ. Malac., vol. 12, no. 3, 1905, pp. 45.46.

Type: Dirona picta COCKerell \& Eliot. 
125. Dirona albolineata MACFARLAND, 1912

\author{
Family Bornellidae \\ Genus Bornella GraY, 1850
}

Bornella GraY, Figs. Mollusc. Anim., vol. 4, 1850, p. 107.

Type: Bornella adamsii GRAY.

126. Bornella digitata ADAMS \& REEvE, 1850

Genus Pseudobornella BABA, 1932

Pseudobornella Baв., Annot. Zool. Japon., vol. 13, no. 4, 1932, pp. 369-370.

Type: Pseudobornella orientalis BABA.

127. Pseudobornella orientalis BABA, 1932

Family Scyllaeidae

Genus Scyllaea LinNÉ, 1758

Scyllaca Linwé, Syst. Nat., ed. 10, 1758, p. 656.

Type: Scyllaea pelagica LinNé.

\title{
128. Scyllaea bicolor BERGH, 1880
}

Scyllaea bicolor BєRG H, Verh. k. k. zool.-bot. Gesell. Wien, Bd. 30, 1880, pp. 15 (167)29 (172), pl. 1, figs. 12-17; pl. 3, figs. 3-6.-Enoshima; Elror, Journ. Coll. Sci. Imp. Univ. Tôkyô, vol. 35, art. 1, 1913, p. 34.-Misaki.

\section{Genus Notobryon ODHNER, 1936}

Notobryon Ouhier, Mém. Mus. Roy. Hist. Nat. Belgique, ser. 2, fasc. 3, 1936, p. 1699.

Type: Notobryon wardi ODHNER.

\section{Notobryon wardi ODHNER, 1936}

(P1. 2, fig. 3; text-fig. 14)

Notobryon wardi Odhner, Mém. Mus. Roy. Hist. Nat. Belgique, ser. 2, fasc. 3, 1936, pp. 1099-1103, pl., figs. 1-3; text-figs. 31 b, 32-38.-Queensland.

Distribution in Japan: Tomioka (Amakusa) and Seto (Kii).

The body is elongated and limaciform, ending posteriorly in a blunt tail. It measures about $60 \mathrm{~mm}$ in the living state. The head is small, but is expanded ventrally in a semicircular veil with a wavy margin. The clavus of the rhinophore is small and conical, 
and bears oblique folds. It is retractile within a stout elevated sheath which terminates distally in a slightly crenulate margin. There is a longitudinal crest or flange along the posterior margin of the sheath. The dorso-lateral margins of the body are produced

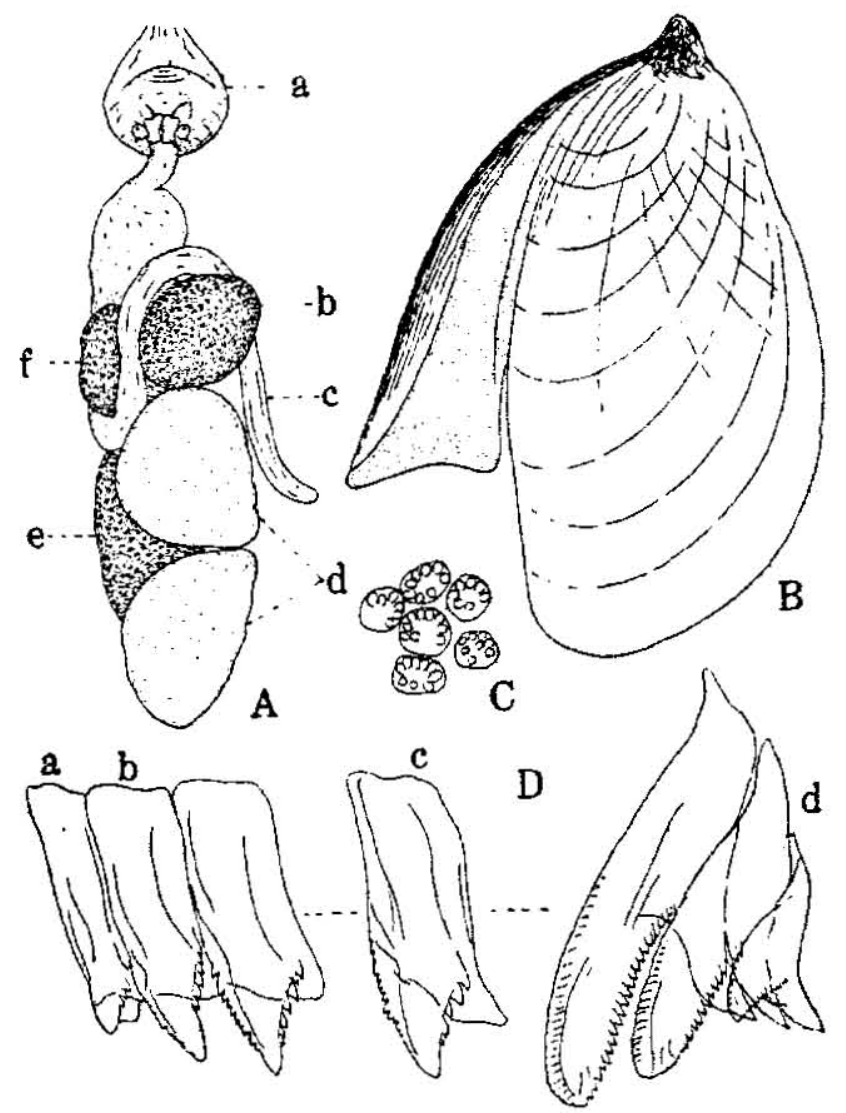

Text-fig. 14.-Notobryon twardi. A. General aspect of digestive organs $(\times 2)$, a. pharyngeal bulb, b. right anterior liver-lobe, c. intestine, d. hermaphrodite gland, e. posterior liver-lobe, f. left anterior liver-lobe; B. Jaw-plate $(\times 10)$; C. Scales on masticatory process $(\times 400)$; D. A half-row of radula $(\times 140)$, a. 1st lateral tooth, b. 2nd tooth, c. 10th tooth, d. outermost teeth.

into two pairs of large foliaceous lobes. The edges of these lobes are indistinctly crenulate, and the tips are rolled to form a sort of short upstanding siphons. The branchial tufts, 4 on each dorsolateral lobe and one at the hinder end of the mantle, are long cylindrical processes which give off branches, themselves dividing into smaller ramose twigs. The back is smooth. The neck has 
on each side a small conical papilla. The sides are fairly smooth though there is a row of (10-12) conical papillae of various sizes extending from the neck to the tail. The tail has a mid-dorsal crest. The foot is narrow but is capable of expansion. It is rounded in front and continued into a blunt tail posteriorly. The anus opens on the right side between the dorso-lateral lobes. The genital orifice lies on the same side a short distance behind the level of the rhinophore sheath.

The general ground-colour of the body is a beautiful saffronyellow with deeper dots and mottles. An olive colour predominates on the rhinophore sheaths, dorso-lateral margins, tail crest, and dorso-lateral lobes. Dorsally there is a bold opaque marking at the base of the dorso-lateral lobe. The papillae on the neck and sides are opaque white. The rhinophore clavi light saffron-yellow; the anal papilla deep red; the branchial plumes colourless; the foot saffron-yellow.

The jaw-plates are shell-shaped and of a horn-yellow colour. The masticatory edge is produced dorsally into a wide flange with a recurved border. This flange is covered everywhere with fine close-fit scales. The radula formulae in two specimens are $13 \times 14$. 20.0.14-20, and $15 \times 14-21.0 .14-21$, respectively. The older end of the radula is black-tinted while the newer end is colourless. In both radulae the rachis is wide and bare, without a central tooth. The 1st lateral tooth is the smallest and is sometimes degraded. Typically it takes the form of an oblong plate which has a short claw-like spine and an outer row of (3-4) denticles. The next lateral tooth has (8.12) inner and (about 5) outer denticles. The succeeding teeth present the same general form, getting larger towards the middle of the half-row. The denticles are decidedly smaller on the inner margin than on the outer. At the extreme end of the row the teeth decrease considerably in size. The stomach has a girdle of black chitinous plates, each being broadly triangular in form with a mammiliform apex. The liver, deep blue black in colour, is divided into two anterior and one posterior lobes, the last of them being the largest. The hermaphrodite gland consists of two large grayish lobes.

Locality: Tomioka (May 1936; 2 sps.) and Seto (Mar. 1937; $1 \mathrm{sp}$.$) .$

I have been able to identify the present specimens as Notobryon 
wardi. They agree with that species in the general body form and in the type of the radula, liver and hermaphrodite gland.

Genus Crosslandia Eliot, 1902

Crosslandia Eurt, Proc. Zool. Soc. London, 1902, pt. 2, pp. 64-€8.

Type: Crosslandia viridis ElioT.

130. Crosslandia viridis ElIOT, 1902

(Pl. 1, fig. 7; text-fig. 15)

Crosslandia viridis Eltot, Proc. Zool. Soc. London, 1902, pt. 2, pp. 64-68, pl. 5, figs. 1.2, 4.8; text-figs. $2 \cdot 4 .-$ Zanzibar.

Crosslandia fusca Eltot, ditto, p. 68, pl. 5, fig. 3.-Zanzibar; Elot, Journ. Linn. Soc. London, Zool., vol. 31, 1908, pp. 90.94, figs. a-c.-Red Sea.

Crosslandia orientalis TüL., Tiefsee-Exped., 1925, p. 287, pl.33, fig. 20.-near Zanzi. bar.

Distribution in Japan: Tomioka (Amakusa).

The living animal measures about $30 \mathrm{~mm}$ in length. It is produced into a long neck and tail, and laterally into two foliaceous lobes, one on each side. The lobe itself has a posterior notch down the tip, showing a sign of subdivision into two halves, the anterior being a little larger than the posterior. The head is small with a triangular veil which has ventrally a slit-like mouth. The rhinophore is small, conical and perfoliated. It is entirely retractile within an elevated sheath whose upper margin is wavy. There is a longitudinal crest along the posterior margin of the sheath. Small conical papillae are borne on the dorso-lateral margins and on the sides of the body. The branchial tufts, about 40 in number, are small and ramose and are irregularly scattered over the inner surface of the foliaceous lobes and on the back between and behind these lobes. The tail has a mid-dorsal crest. The genital orifice lies on the right side immediately behind the rhinophore sheath. The anus is situated on the same side just beneath the foliaceous lobe. The foot is small with an abruptly rounded anterior edge.

The upper side of the body is of a translucent yellowish brown sparsely maculated with white, and is ornamented with additional blue markings. Of these latter, one is on the rhinophore sheath, two on the mid-dorsal line, about 15 along the margin of the foliaceous lobe, and 3.4 on the side of the body.

The jaw-plates are shallow shell-shaped. At the dorsal edge it 
is produced into a wide masticatory process with a recurved border. This process is covered as usual with fine, closely approximated scales. The radula formula is $18 \times 16-22.1 .16 .22$. The central tooth is small and consists of an oblong base bearing a
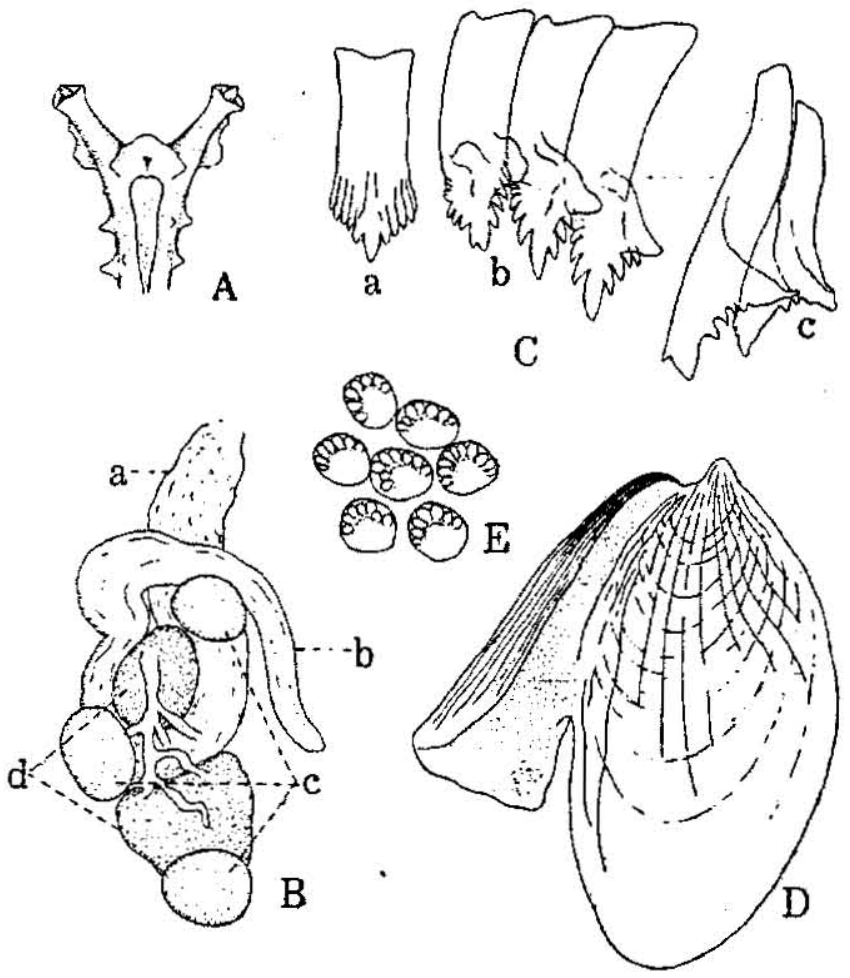

Text-fig. 15.-Crosslandia viridis. A. Mouth-parts; B. General aspect of digestive organs $(x 4)$, a. oesophagus, b. intestine, c. hermaphrodite glands, d. liver-lobes; C. A half-row of radula $(\times 200)$, a. central tooth, b. innermost Iateral teeth, c. outermost teeth; D. Jaw-plate $(\times 18)$; E. Scales on masticatory process $(\times 470)$.

series of $4-6$ denticles on both sides of a small median cusp. The 1st lateral tooth is plate-like with $3-5$ denticles on both sides of a small median cusp. The succeeding teeth do not differ much in shape from the 1st tooth, but get larger as they pass outward. At the extreme end of the row the teeth decrease in size, becoming roughly hamate with irregular flanking denticles.

The stomach is armed with a girdle of chitinous plates which are colourless and triangular in shape. The liver is in two large masses, anterior and posterior. The hermaphordite glands consist of 3 spherical masses.

Locality: Tomioka (Feb. 1935; $1 \mathrm{sp.}$.). 
In 1902 ELIOT created two species, Crosslandia viridis and $C$. fusca, which, however, were subsequently regarded by him (1908) as varieties of a single species. In 1929 O'Donoghue accepted viridis as the type of the genus Crosslandia and fusca as a synonym. C. viridis ElIoT is known to be subject to a vast range of colour variation, from brown to green, and to this species, in particular to its brown form, is referable the present Japanese specimen.

Family Phylliroidae

Genus Phylliroe Péron \& Lesueur, 1810

Phylliroe Pérox: \& Lesuetr, Ann. Mus. Hist. Nat., tom. 15, 1810, p. $6 \overline{5}$.

Type: Phylliroe bucephala PÉron \& Lesueur.

131. Phylliroe bucephala PÉRON \& Lesueur, 1810

Phylliroe bucepinala Pérnx \& Lesceur, Ann. Mus. Hist. Nat., tom. 15, 1810, p. 65, pl. 2, figs. 1-3; Etıт, Journ. Coll. Sci. Imp. Univ. Tôkyô, vol. 35, art. 1, 1913, p. 34. -Bonin Islands.

Genus Cephalopyge Hanel, 1905

Cephalopyge Havel, Zool. Jahrb., Syst., Bd. 21, 1905, pp. 451-462.

Type: Phylliroe tromatoides CHUN.

132. Cephalotyge arientalis BABA, 1933

Family Fimbriidae (=Tethyidae, Tethymelibidae)

Genus Melibe RANG, 1829

Melibe Ravo, Manuel Mollusq., 1829, p. 129.

Type: Milibe rosea RANG.

Synopsis of the Japanese species:

A. Foot very much expanded, hood large, body enormous (250-500 $\mathrm{mm}$ long)

B. Foot very narrow, hood of moderate size, body not large.

1. Cirri of hood-margin few, in 1.3 rows; body small, pale yellow with sparsely $\begin{array}{llllllllllll}\text { set brownish mottles } \ldots & \ldots & \ldots & \ldots & \ldots & \ldots & \ldots & \ldots & \ldots & \ldots & \text { papillosa. }\end{array}$

2. Cirri of hood-margin many, in $5-10$ rows.

a. Lip reddish brown, body reddish brown with dark shades and mottles

$\begin{array}{rlllllllll}\ldots & \ldots & \ldots & \ldots & \ldots & \ldots & \ldots & \ldots & \ldots & \text { pilosa. }\end{array}$

b. Lip not reddish brown, body yellowish brown... $\quad \ldots \quad \ldots \quad \ldots \quad$ vexillifera. 


\section{Melibe pilosa PeAse, 1860}

134. Melibe papillosa (DE FILIPPI, 1867)

135. Melibe vexillifera $\mathrm{BERGH}, 1880$

Melibe vexillifera BERGH, Verh. k. k. zool.bot. Gesell. Wien, Bd. 30, 1880, pp. 10 (162)13 (165), pl. 2, figs. 1.11 ; pl. 3, figs. 1.2.-Enoshima.

Melibe vexillifera? E七юr, Journ. Coll. Sci. Imp. Univ. Tôkyô, vol. 35, art. 1, 1913, p. 37. pl. 2, fig. 11; Htrasé, Moluskoj, 1927, p. 1475, fig. 2837.-Misaki.

136. Melibe japonica ELIOT, 1913

Family Dotonidae

Genus Doto OKen, 1815

Doto OKEN, Lehrb. Naturg., Th. 3, Zool., pt. 1. 1815, pp. 10, 278.

Type: Doris maculata MonTAgu.

137. Doto japonica ODHNER, 1936

Doto japonica Odhner, Mém. Mus. Roy. Hist. Nat. Belgique, ser. 2, fasc. 3, 1936, pp. 1121.1122, pl., figs. 11.16; text-fig. 47.-Moroiso near Misaki.

Family Madrellidae

Genus Madrella Alder \& HanCock, 1864

Madrella Alder \& Hancock, Trans. Zool. Soc. London, vol. 5, pt. 3, 1864, pp. 141-142.

Type: Madrella ferruginosa AldER \& HANCOCK.

138. Madrella sanguinea (ANGAS, 1864)

(Pl. 1, fig. 2)

Family Flabellinidae

Genus Coryphella GRAY, 1850

Coryphella GraY, Figs. Mollusc. Anim., vol. 4, 1850, p. 109.

Type: Eolis rufibranchialis JoHnston.

Synopsis of the Japanese species:

a. Branchial papillae many, in (30) oblique rows on each side ... $\ldots . \ldots$ athadona.

b. Branchial papillae very few, 6-7 groups on each side, each group containing

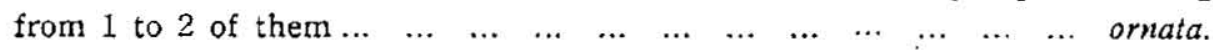

139. Coryphella alderi ADAMS, 1861

Coryphella alderi ADAms, Ann. Mag. Nat. Hist., ser. 3, vol. 8, 1861, p. 140.-Off Fuku. yama, Tsugaru Straiț. 


\title{
140. Coryphella athadona BERGH, 1875
}

- 141. Coryphella ornata RISBEC, 1928

\author{
Family Tergipedidae
}

\section{Genus Cuthona Alder \& Hancock, 1855}

Cuthona Alder \& Hancock, Monogr. Brit. Nudib., pt. 7, 1855, appendix, p. 22.

Type: Eolis nana ALDER \& HANCOCK.

Cuthona, with Cratena, Amphorina (of some authors), Hervia and Rizzolia as synonyms, may possibly be classified as follows:

Subgenus Cuthona s.s. (+ Cratena, Amphorina spp. of some authors). Antero-lateral corners of foot rounded, or slightly angulated.

Subgenus Hervia Bergh, 1871. (+ Rizzolia). Antero-lateral corners of foot tentaculiform.

\section{Synopsis of the Japanese species belonging to the subgenus Cuthona:}

a. Branchial rows many (15-19); teeth numerous (70-82); each comb-like with 8-10 denticles in front, median spine indistinct. Body orange-yellow, branchial papillae orange-yellow with a dark blue vein and a white tip ... ... bicolor.

b. Branchial rows 8.9 ; teeth few (15), each horseshoe-shaped with a prominent median cusp and 5.6 flanking denticles. Back, rhinophores and oral tentacles

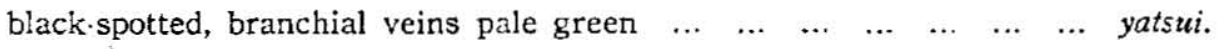

142. Cuthona (Cuthona) bicolor BERGH, 1904

143. Cuthona (Cuthona) sp. ELIOT, 1913

Amphorina? sp. Elor, Journ. Coll. Sci. Imp. Univ. Tôkyô, vol. 35, art. 1, 1913, p. 43. -Misaki

\section{Cuthona (Cuthona) yatsui (BÄBA, 1930)}

(P1. 2, fig. 2)

145. Cuthona (Cuthona) sp. BABA, 1935

\section{Synopsis of the Japanese species belonging to the subgenus Hervia:}

1. Branchial papillae in many $(9-17)$ oblique rows.

a. Genital orifice below the 4 th right branchial row. Two chocolate lines on $\begin{array}{lllllllllll}\text { each side of body } & \ldots & \ldots & \ldots & \ldots & \ldots & \ldots & \ldots & \ldots & \ldots & \text { quadrilineata. }\end{array}$

b. Genital orifice below the 2nd right branchial row. Body orange-yellow, branchial papillae yellow with a cobalt-blue vein ... ... ornata nov. sp.

2. Branchial papillae in (4-8) groups and on horseshoe-shaped bases, the Ist group being widely separated from the rest.

a. Genital orifice below the 2nd right branchial row. Branchial groups from 
2nd to last moderately close together. Body yellowish, branchial veins reddish brown, yollowish brown, deep orange yellow or chrome yellow $\begin{array}{llllllllll}\ldots & \ldots & \ldots & \ldots & \ldots & \ldots & \ldots & \ldots & \ldots & \text { ceylonica. }\end{array}$

b. Genital orifice below the 2nd right branchial row. Branchial groups from 3rd to last very close together and moderately separated from the 2nd. Body white, branchial veins reddish brown $\ldots . . \ldots \quad \ldots \quad \ldots \quad$ enosimensis.

c. Genital orifice below and between the 1st and 2nd right branchial groups. $\begin{array}{lllllllllll}\text { Tail very long } & \ldots & \ldots & \ldots & \ldots & \ldots & \ldots & \ldots & \ldots & \ldots & \text { japonica nom. nov. }\end{array}$

d. Genital orifice below the 1st right branchial row. Back and sides with

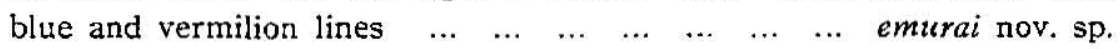

146. ? Cuthona (Hervia) rosea (BERGH, 1888)

Hervia rosea? Eltot, Journ. Coll. Sci. Imp. Univ. Tôkyô, vol. 35, art. 1, 1913, pp. 4243.-Misaki.

147. Cuthona (Hervia) ceylonica (FARRAN, 1905)

148. Cuthona (Hervia) enosimensis (BABA, 1930)

In my previous paper (BABA 1930, pp. 118-119) the branchial papillae have been described to be in 3 groups on each side. The reexamination of the original specimen reveals that the apparent 3 rd group consists of $2 \cdot 3$ small, closely approximating groups, each lying upon a horseshoe-shaped base. In all, therefore, the branchial groups are 4 on the left and 5 on the right side.

149. Cuthona (Hervia) quadrilineata (BABA, 1930)

150. Cuthona (Hervia) quadrilineata (BABA, 1930), variety

151. Cuthona (Hervia) japonica nom. nov.

Rizzolia modesta B:Rsu, Verh. k. k. zool.-bot. Gesell. Wien, BJ. 30, 1880, p. 4 (156)-8

(160), pl. 1, figs. 1-11.-Enoshima; ? Et.1.т, Proc. Malac. Soc. London, vol. 6, pt. 4, 19J5, pp. 230-231.-Inland Sea.

Rizzolia modesta of BERGH appears to be a distinct species of the genus Cuthona. I propose to call it as above because the name $m$ odesta is preoccupied (Hervia modesta BERGH, 1874).

152. Cuthona (Hervia) emurai nov. sp.

(Text-fig. 16)

Distribution in Japan: Niigata (Japan Sea).

Several specimens accompanied by a coloured sketch have 
been sent for identification by Prof. Emura of Niigata Kôtô-Gakkô. The body in life ranges from 10 to $35 \mathrm{~mm}$ in length. The anterolateral corners of the head are continued out into two strong pointed oral tentacles. The rhinophores are shorter, being constricted along the whole length but not perfoliated. The branchial papillae are fusiform, very deciduous and arranged superficially in 3 tufts, but actually in 5-6 groups on each side of the body. Each group lies upon a roughly horseshoe-shaped base opening outward. The 1st group commences posterolateral to the rhinophore, contains over 50 papillae, and is widely separated from the 2 nd. The genital opening lies immediately below the 1st group on the right side. The 2nd group, with nearly 50 papillae, is as large as the 1st,

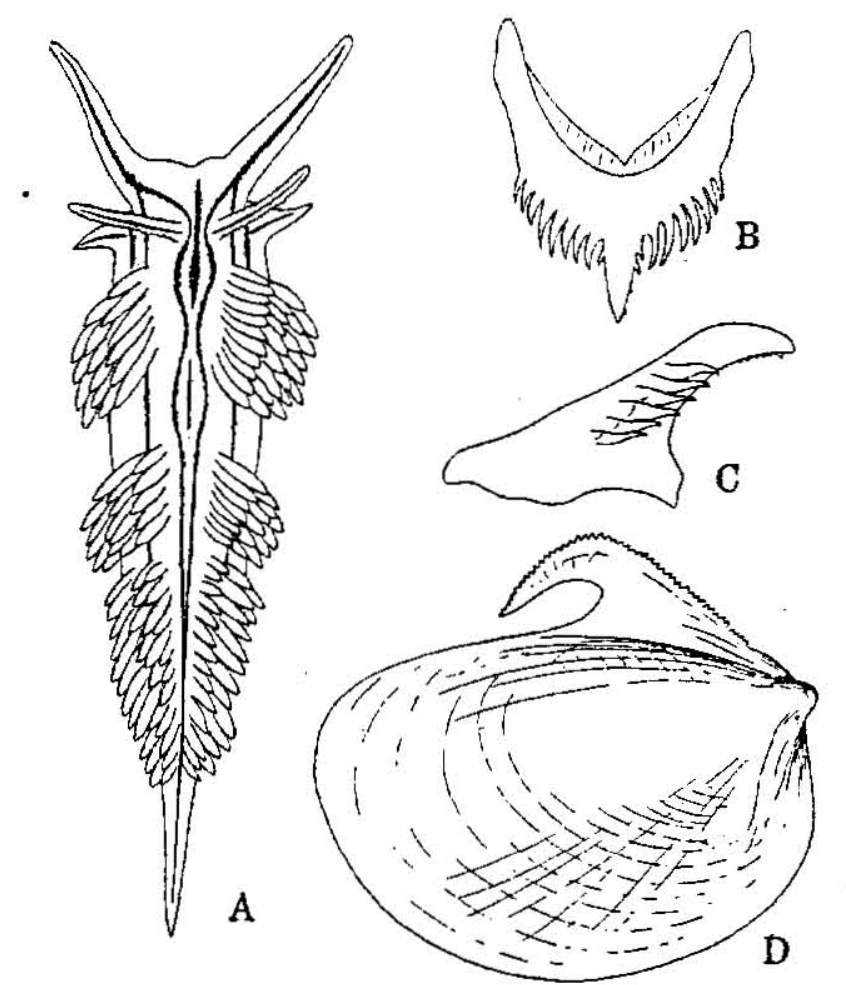

Text-fig. 16.-Cuthona emurai. A. Entire animal $(x 2)$; $B$. Tooth in dorsal view $(\times 60)$; C. The same in latera! view; D. Jaw-plate $(\times 10)$. The original sketch of the animal has been made from life by Prof. EMur.l.

and on the right side it surrounds the anal papilla. The succeeding groups are close together, and decrease in size as they pass backwards. In the last group the papillae are crowded irregularly so as to cover the posterior extremity of the back. The foot 
is bilabiate with a notch in the middle of the upper lip, and is continued out laterally into two well-marked tentaculiform processes.

The ground-colour of the body is of a pale (fleshy) yellow. Along the mid-dorsal region there run two bluish bilateral lines which pass forward and run right up the rhinophores and oral tentacles; posteriorly they converge to the tip of the tail. A broken mid-dorsal vermilion line runs about half way down from the head. The sides of the body are each marked with two lines running parallel with each other, the upper bluish and the lower shorter and vermilion. The branchial papillae are chocolate-coloured with usually a white vein and a vermilion marking immediately below the whitish tip, sometimes a white broken vein running up to the tip. The antero-lateral tentaculiform processes of the foot are each marked with a bluish line.

The cutting edge of the jaw-plate is continued out in a strong pointed masticatory process bearing a series of (55) denticles. The radula is uniseriate with about 20 teeth and is formulated as $20 \times$ 0.1.0. Each tooth is of a characteristic horseshoe-shape. The apex is marked by a strong median spine flanked by $1-2$ small denticles near the base; ventrally and distally the spine bears a series of (6-8) almost indistinct denticles. On each side of the median spine there runs a row of sharp denticles, the latter varying from 6 to 7 in number.

Locality: Niigata (Apr. 1934; fairly common).

This is a new species characteristic especially of colours, arrangement of the branchiae, and position of the genital orifice.

\section{Cuthona (Hervia) ornata nov. sp.}

(Pl. 2, fig. 4 ; text-fig. 17)

Distribution in Japan: Tomioka (Amakusa).

The body in life ranges from 8 to $12 \mathrm{~mm}$ in length. The antero-lateral corners of the head are continued out into two slender oral tentacles. The rhinophores are a little longer, and are simply cylindrico-conical without perfoliations. The margin of the back bears a small number of branchial papillae in 9 transverse rows, the largest being on the inside and the smallest outside. They are small, short and roughly fusiform, and are about 2 in the 1st, 4 in the 2nd, 5 in the 3 rd and 4 th, 4 in the 5 th and 6 th, 3 in the 7 th and 8 th, and 1 in the 9th row. The end of the body extends 
in a long tail behind the level of the last rows. The anal papilla lies between the 4 th and 5 th rows on the right side. The genital orifice is situated below the 2 nd row "on the same side. The foot
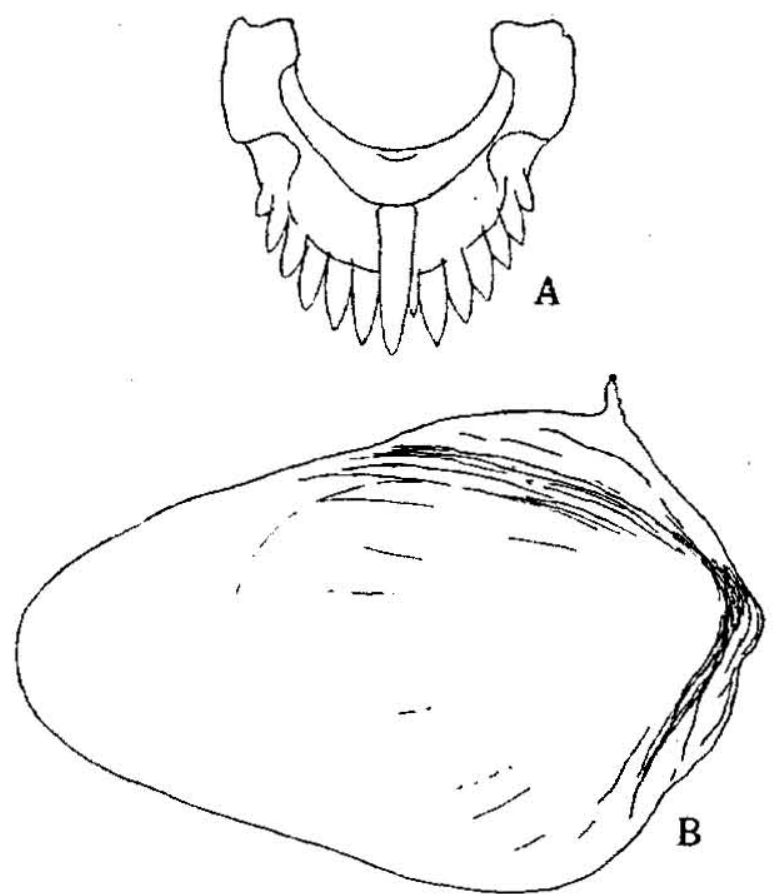

Text-fig. 17. Cuthona ornata. A. Tooth $(\times 230)$; B. Jaw. plate $(\times 70)$.

is fairly narrow; the front edge is rounded off and its corners are produced outward into two horn-like processes.

The general colour of the head, back and sides is orangeyellow and this also is true of the basal half of the rhinophores and oral tentacles. The branchial papillae are yellow with a cobalt-blue vein which terminates distally in an opaque yellow marking. The upper half of the rhinophores and oral tentacles are yellow.

The jaw-plates are shell-shaped with a short masticatory process. The cutting edge probably bears a series of denticles which are now worn jagged. The uniseriate radula consists of 55 teeth and is formulated as $55 \times 0.1 .0$. The tooth is roughly horseshoe-shaped. In front it is marked by a fairly stout median spine rising far back, on each side of which runs a row of $5-7$ sharp denticles, some of the denticles being smaller than others.

Locality: Tomioka (Mar. $1935 ; 2$ sps.). 
This species resembles Cuthona (Hervia) sibogae (BERGH) in the body form (and probably in the radula consisting of numerous teeth), but cannot be safely identified with that species by having a different coloration and a fairly stout median spine of the teeth.

Family Fionidae

Genus Fiona Forbes \& HaNLEY, 1851

Fiona Firzes \& Hancer, Brit. Moll., pts. 41-42, vol. 3 (contents, p. 10, note), 1851.

Type: Oithona nobilis Forbes \& HANLEY.

\section{Fiona pinnata (ESCHSCHOLTZ, 1831)}

Eolidia pinnata Escrischıtr, Zool. Atlas, Hft. 4, 1831, p. 14, pl. 19, fig. 1.-Sitka (Alaska). Fiona pinnata BERGH, Verh. k. k. zool.-bot. Gesell. Wien, Bd. 23, 1873, pp. 6C9.610.-Japan.

Fiona marina Eìıor, Journ. Coll. Sci. Inp. Univ. Tôkyô, vol. 55, art. 1, 1913, pp. 4445.--Japan.

Family Aeolidiidae

Subfamily Favorininae

Genus Favorinus GraY, 1850

Favorintus Gray, Figs. Mollus:. Anim., vol. 4, 1850, p. 109.

Type: Eolis alba ALDER \& HANCOCK.

155. Favorinus pacificus nov. sp.

(Pl. 2, fig. 7; text-fig. 18)

Distribution in Japan: Tomioka (Amakusa).

The body in life measures about $10 \mathrm{~mm}$ in length. The anterolateral corners of the head are continued out into two exceedingly slender oral tentacles. The rhinophores are a little shorter and cylindrico-conical, with indistinct constrictions along the whole length. The margin of the back bears a small number of fusiform branchial papillae in 7 oblique rows, the largest being on the inside and the smallest outside; they are about 3 in the 1st, 2nd, 3rd and 4 th rows, and 2 in the succeeding rows. The foot is fairly narrow, passing off to a point behind. The front edge is rounded off and its corners are produced outward into tentaculiform processes. 
The general colour of the body is a translucent white and this also is true of the oral tentacles, tail and foot. The rhinophores are chocolate-tinted, except at the distal third which is colourless.

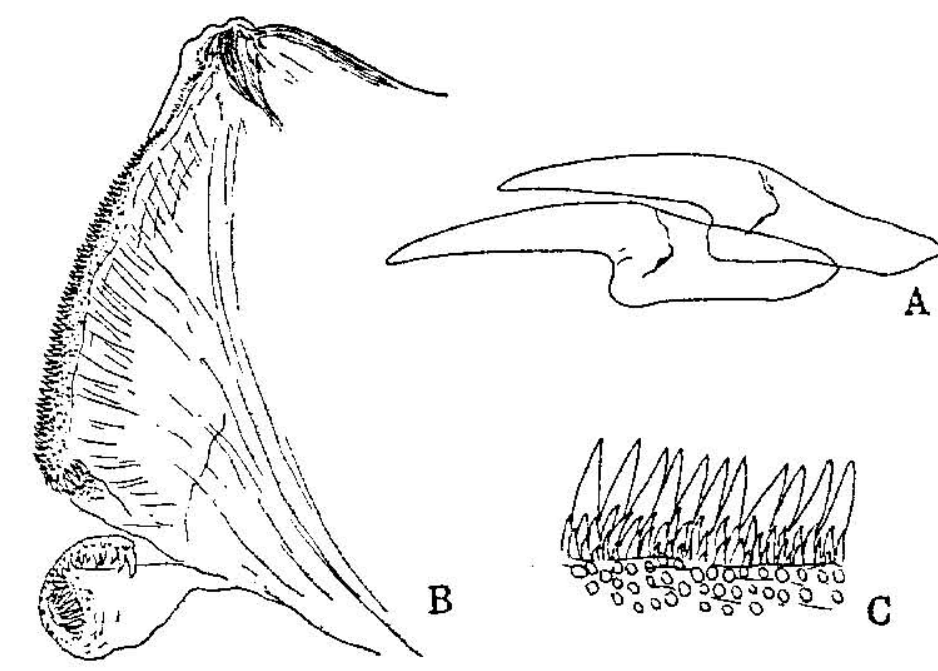

Text-fig. 18.-Favorinus pacificts. A. Lateral view of teeth $(\times 220)$; B. Masticatory process of jaw-plate $(\times 90)$; C. Masticatory edge $(\times 300)$.

The branchial papillae are dark yellow almost up to the tip which terminates in a white cap, with a purple marking below.

The jaw-plates have a produced masticatory process. The whole length of the cutting edge is armed with a series of closely set spiny denticles, at the base of which are several (2-3) rows of small additional denticles. The uniseriate radula contains about 21 teeth and is formulated as $21 \times 0.1 .0$. The tooth consists of a $\mathrm{V}$-shaped base bearing in front a large median spine. The latter is quite smooth without any trace of denticle.

Locality: Tomioka (Feb. 1935; 1 sp.).

This species to a certain extent in its general appearance and type of radula recalls Favorinus albus (ALDER \& HANCOCK). But it has a different arrangement of branchial papillae and also a somewhat different coloration, and I propose to put it on record as a new species with the name $F$. pacificus.

Genus Pteraeolidia BERGH, 1875

Pleraeolidia Bergit, Verh. k. k. zool.-bot. Gesell. Wien, Bd. 25, 1875, p. 652 .

Type: Flabellina semperi BERGH. 
15̄6. Pteraeolidia semperi (BERGH, 1870)

Subfamily Phyllodesmiinae

Genus Phyllodesmium Ehrenberg, 1831

Phyllodesmitum Ehrengerg, Symb. phys., 1831.

Type: Phyllodesmium hyalinum EHRENBerg.

157. Phyllodesmium hyalinum EHRENBERG, 1831

(Pl. 2, fig. 5)

Subfamily Aeolidiinae

Genus Aeolidia Cuvier, 1798

Aeolidia Cuvier, Tabl. élém. Hist. Nat., 1798, p. 388.

Type: Limax papillosus LINNÉ.

158. Aeolidia papillosa (Linné, 1761)

Genus Baeolidia BERGH, 1888

Baeolidia Bergh, Malac. Unters., Hft. 16, pt. 1, 1888, pp. 777.778 .

Type: Baeolidia moebii BERGH.

Synopsis of the Japanese species:

a. Body large $(40.70 \mathrm{~mm})$, branchial groups many $(10 \cdot 15)$, tooth very broad

$\begin{array}{lllllllllll} & \ldots & \ldots & \ldots & \ldots & \ldots & \ldots & \ldots & \ldots & \ldots & \text { major amakusana nov. subsp. }\end{array}$

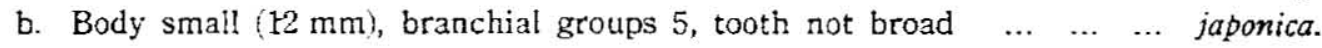

159. Baeolidia major amakusana nov. subsp ${ }^{12}$.

(P1. 1, fig. 10)

Baeolidia major Bsas, Annot. Zool. Japon., vol. 14, no. 1, 1933, p. 178.-Tomioka.

As our specimen previously referred to Baeolidia major is different from the type of ELIOT in the position of the anus, it seems better to call the former B. major amakusana nov. subsp. Two more specimens from Tomioka (length 35 and $70 \mathrm{~mm}$ respectively) have been examined. The rhinophore is closely studded with small round granules in irregular rows. The branchial papillae are in about $12-15$ groups, each lying upon a horseshoeshaped base. The back is yellowish brown spotted with yellow,

1) Baeolidia major at p. 201 (Opisthobranchia of Japan, I), is altered to B. $m$. amakusana. 
paler on the pericardium. The branchial papillae have dark brown liver diverticula shining through the integument which is spotted with yellow.

\section{Baeolidia japonica BABA, 1933}

A few remarks may be added to the previous description. The branchial papillae are arranged on both sides in about 5 groups, the first two lying upon horseshoe-shaped bases and the remainder upon simple oblique bases. The genital orifice lies immediately below the Ist group and the anus in the centre of the 2nd group on the right side. The body is dark brown, covered with white spots which are most conspicuous on the back and head.

\section{Genus Eolidina Quatrefages, 1843}

Eolidina Quatrefages, Ann. Sci. Nat., Zool., ser. 2, tom. 19, 1843, p. 276.

Acolidiella Bergh, Vidensk. Meddel. Naturh. Foren., (1866) 1867, p. 99.

\section{Type: Eolidina paradoxum QuATREFAGES.}

With 3 subgenera, viz. Eolidina s. s. (Aeolidiella), Spurilla and Berghia.

Synopsis of the Japanese species:

a. Body stout, rhinophores with $2 \cdot 3$ annular swellings, antero-lateral corners of

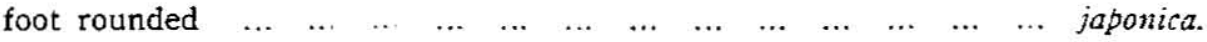

b. Bufy snall, rhinophores smooth, antero-lateral corners of foot slightly angulated $\begin{array}{llllllllll}\ldots & \ldots & \ldots & \ldots & \ldots & \ldots & \ldots & \ldots & \ldots & \text { takanosimensis. }\end{array}$

161. Eolidina (Eolidina) japonica (ELIOT, 1913)

162. Eolidina (Eolidina) takanosimensis (BABA, 1930)

Subfamily Glaucinae

\section{Genus Glaucus Forster, 1777}

Glaucus FuRster, Voy. Resolution, 1, 1777, p. 49.

Type: Glaucus atlanticus FORSTER.

163. Glaucus marinus (Dupont, 1763)

Hirudo marina Dupunt, Phil. Trans. Roy. Soc., 1763, p. 57.

Glaucus lineatus Etıor, Journ. Coll. Sci. Imp. Univ. Tôkyô, vol. 35, art. 1, 1913, pp 45. 46.-Sagami Sea; HIRAsÉ, Moluskoj, 1927, p. 1475, fig. 2838--Kii, Sagami. 


\section{SUMMARY}

This paper gives a comprehensive list of the species of Nudibranchia from Japanese waters. The following eleven are recognized as new species: Euphurus ornatus, Polycera fujitai, Goniodoris glabra, Okenia barnardi, Noumea nivalis, Geitodoris lutea, Thordisa amakusana, Discodoris pallida, Cuthona emurai, C. ornata, Favorinus pacificus.

The following two are regarded as new subspecies: Marionia pustulosa odhneri, Baeolidia major amakusana.

Two new specific names have been proposed for the previously noted forms:-Phyllidia japonica, Cuthona japonica.

\section{CORRECTION OF ERRORS IN "OPISTHOBRANCHIA OF JAPAN (I)"}

P. 196, line 21, for “The Foundation for the Promotion of Scientific and Industrial Research of Japan," read "The Japan Society for the Promotion of Szientific Research."

P. 211, line 4, for "Tethys japonica (CLessin, 1899)," read " $T$. sieboldiana (CLrssis, 1899)," See Clessin (1899), p. 54.

P. 222, line 27, for "colour," read "ground-colour."

P. 223, line 5, for "descending," read " ascending;" line 6, for " ascending," read "descending."

P. $22 \hat{j}$, line 14, for " ascending," read " descending;" line 15, for " descending," read "ascending."

P. 234, line 41 , for "Si, T.", read "Tchang Si."

\section{POSTSCRIPT}

Pleurobranchaea japonica has been recorded by the late Prof. J. Tulses from Kôbe, Japan (Gastrop. d. Deutsch. Tiefsee-Exped., Th. 2, 1925, p. 283, pl. 33, fig. 8). The description is very short, but it appears probable that this is identical with the common Japanese species, $P$. novaezealandiae Cheesemas (see "Opisthobranchia of Japan," I, p. 229'. 


\section{BIBLIOGRAPHY}

Algzr, J. \& A. Hakiocx 1845 Notice of a new genus and several new species of nudibranchiate mollusea. Ann. Mag. Nat. Hist., ser. 1, vol. 16.

-- $185 \overline{5}$ A monograph of the British nudibranchiate mollusca, with figures of all the species. pt. 7 , appendix.

Allas, J. K. 1932 A new genus and species of sea-siug, and twa new species of sea-hares from Australia. Rec. Austral. Mus., vol. 18, no. 6.

- 1932 Australian nudibranchs. Austr. Zoologist, vol. 7, pt. 2.

BABA, K. 1937 Opisthobranchia of Japan (I). Journ. Dept. Agric. Kyûshû Imp. Univ., vol. 5 , no. 4.

- 1937 Contribution to the knowledge of a nudibranch, Okadaia Elegans Bate. Japan. Journ. Zool., vol. 7 , no. 2.

- 1937 Note on the colour variation of a dorid, Rostanga arbutus (Avcas, 1864). Venus, vol. 7 , no. 1 .

-1. 1937 Two new species of the nudibranchiate genus Cadlina from Sagami Bay, Japan. Venus, vol. 7 , no. 2 .

- 1937 Record of a nudibranch, Gymnodoris striata (E七corj, from Amakusa, Japan. Zool. Mag. (Japan), val. 49, no. 6.

BzRGH, R. 1874 Malacologische Untersuchungen, Hft. 6.

- 1874 Neue Nacktschnecken der Südsee. 2. Journ. Mus. Godeffroy, Hft. 6.

- 1875 Neue Nacktschnecken der Südsee. 3. Journ. Mus. Godeffroy, Hft. 8.

- 1877 Kritische Untersuchungen der EureNberg'schen Doriden. Jahrb. Deusch. Malakoz. Gesell., Bd. 4.

- 1878 Malacologische Untersuchungen, Hft. 13.

—_ 1879 Gattungen nordischer Doriden. Arch. f. Naturgesch., Jahrg. 45, Bd. 1.

- 133) Die Gattunz Guniodaris Furbes. Malakoz. Blätt., Bd. 2.

- 1888 Beiträge zur Kenntniss der Aeolidiaden. 9. Verh. k. k. zool.-bot. Gesell. Wien, Bd. 38.

- 1888 Die Pleuroleuriden, eine Familie der nudibranchiaten Gasträopoden. Zool. Jahrb., Syst., Bd. 3.

… 1892 Die cryptobranchiaten Dorididen. Zool, Jahrb., Syst., Bd. 6.

1894 Die Opisthobranchien. Bull. Mus. Comp. Zool. Harvard, vol. 25, no. 10.

Cockerglt, T. D. A. \& C. Esw 1905 Notes on a collection of Californian nudibranchs. Journ. Malac., vol. 12, no. 3.

Eltot, C. 1932 On some nudibranchs from Zanzibar. Proc. Zool. Soc. London, pt. 2.

-. 1904 On some nudibranchs from East Africa and Zanzibar. pt. 4. Dorididae Cryptobranchiatae, 2. Proc. Zool. Soc. London, pt. 1.

- 1905 Nudibranchs from the Indo-Pacific. 1. Notes on a collection dredged near Karachi and Maskat. Journ. Conch., London, vol. 11, no. 8.

HANEL, E. 1905 Cephalopyge trematoides (CHUN). Eine neue Mollusken-Gattung. Zool. Jahrb., Syst., Bd. 21.

Hirasé, S. 1937 On a new Berthella from Japan. Proc. Malac. Soc. London, vol. 22, pt. 4.

KelaArt, E. F. 1858 Description of a new Ceylonese nudibranch. Ann. Mag. Nat. Hist., ser. 3, vol. 1 .

MacFarland, F. M. 1931 Drepanida, new name for Drepania Lafont, preoccupied. Nautilus, vol. 45 , no. 1 . 
Prevot-Fot, A. 1930 Du genre Dendrodoris Ehrenrerg et de ses rapports avec le genre Doriopsis Pease et avec quelques autres. Note sur la taxonomie des nudi. branches. Bull. Mus. Hist. Nat. Paris, ser. 2, tom. 2, no. 3.

- 1931 Notes de systématique sur les opisthobranches (suite). Bull. Mus. Hist. Nat. Paris, ser. 2, tom. 3, no. 8.

Vatsstère, A. 1877 . On a new genus of the family Tritoniidae. Ann. Mag. Nat. Hist., ser. 4, vol. 20.

1879 Description du Marionia berghii. Journ. Conchyl., Paris, tom. 27.

1901,1919 Recherches zoologiques et anatomiques sur les mollusques opistobranches du Golfe de Marseille. Ann. Mus. Hist. Nat. Marseille, toms. 6, 17. 


\title{
INDEX OF THE GENERA AND SPECIES
}

\author{
(I $)=$ Opisthobranchia of Japan I \\ (II) = Opisthobranchia of Japan II
}

Acanthodoris (II) 293 pilosa (I) 199, (II) 294 uchidai (II) 294

Aclesia freeri (I) 218

Actinocyclus (II) 300 japonicus (I) 202, (II) 300

Aeolidia (II) 335 papillosa (I) 199, (II) 335

Aeolidiella (II) 336

Aglaia (I) 204 cyanea (I) 201, 205 gigliolii (I) 197, 202, 204

Aglaja (I) 204 cyanea var. vittata (I) 205

Albania formosa (I) 197

Amphorina (II) 328

Apiysia (I) 207 atromarginata (I; 208 euchlora (I) 197, 208 fimbriata (I) 196 japonica (I) 197, 211 laevigata (I) 196 marginata (I) 197, 208 marmorea (I) 197, 208 nigrocincta (I) 208 parvula (I) 208 sibogae (I) 211

Argus (II) 307 cruentus (I) 201, (II) 308 esakii (II) 308 speciosus (I) 198, 201, (II) 308 striatus (I) 201, (II) 308 tabulatus (I) 198, 201, (II) 308

Armina (II) 317

babai (II) 320

comta (I) 198,202 , (II) 320

fallax (I) 198,202 , (II) 320 iaira (I) 197,202 , (II) 320 japonica (I) 202, (II) 320 papillata (II) 320 similis (I) 202, (II) 320 taeniolata (I) 201, (II) 318 variolosa (II) 320

Asteronotus (II) 307 cespitosus (I) 201 , (II) 307

Baeolidia (II) 335 japonica (II) 336 major (I) 201, (II) 335 major amakusana (II) 335

Berthella (I) 227 borneensis (I) 227 gotoi (I) 227 plumula delicata (I) 201,227

Bornella (II) 321 digitata (I) 201, (II) 321

Bulla hirundinina (I) 206

Bursatella leachii var. freeri (I) 218 leachii var. hirasei (I) 218

Cadlina (II) 299 japonica (II) 299 sagamiensis (II) 299

Calliopaea dendritica (I) 223

Caloplocamus (II) 292, 293 croceus (II) 293 ramosus (I) 197, 198, 200, (II) 293

Casella (II) 300 atromarginata (I) 201, (II) 300

Cephalopyge (II) 326 orientalis (I) 200, (II) 326

Ceratosoma (II) 300 cornigerum (I) 198, 201, (II) 300

Chelidonura (I) 206 hirundinina (I) 201, 206

Chromodoris (II) 297 alderi (I) 197 aureopurpurea (I) 198 clitonota (II) 298 marenzelleri (I) 198 pantharella (I) 197 petechialis (I) 198 sibogae (II) 298 thalassopora (I) 197, (II) 297

Coryphella (II) 327 alderi (I) 197, 202, (II) 327 
athadona (I) 197,199 , (II) 328 ornata (I) 201, (II) 328

Cratena (II) 328

Crosslandia (II) 324

fusca (II) 324

orientalis (II) 324

viridis (I) 201 , (II) 324

Cryptophthalmus (I) 202

smaragdinus (I) 201, 202

Ctenodoris (II) 301

aurantiaca (I) 202, (II) 301

Cuthona (II) 328

bicolor (I) 202, (II) 328

ceylonica (I) 198, 201, (II) 329

emurai (I) 199, (II) 329

enosimensis (II) 329

japonica (II) 329

ornata (II) 331

quadrilineata (II) 329

quadrilineata var. (II) 329

rosea (II) 329

yatsui (II) 328

Cyerce (I) 221

nigricans (I) 201,222

Dendrodoris (II) 308

elongata (II) 309

gemmacea (I) 198, 201, (II) 309

guttata (I) 201, (II) 309

miniata (II) 309

nigra (I) 196, 197, 198, 201, (II) 309

nigra var. (II) 309

rubra var. nigromaculata (I) 202 , (II) 309

tuberculosa (I) 201

tuberculosa var. (II) 309

Dermatobranchus (II) 316

striatus (I) 201 , (II) 316

Dirona (II) 320 albolineata (I) 199, (II) 321

Discodoris (II) 305

concinna (I) 201, (II) 305

pallida (II) 305

pardalis (I) 201, (II) 305

yaeyamensis (II) 305

Dolabella (I) 221

scapula (I) 201, 221
Dolabrifera (I) 215

dolabrifera (I) 201, 216

tahitensis (I) 216

Doridium (I) 204 cyaneum var. vittatum (I) 205

Doridopsis (II) 308 gemmacea (I) 198

indacus (I) 197

Doriopsis (II) 308 nigra var. coerulea (I) 198 viridis (I) 197, 201, (II) 308

Doriprismatica festiva (I) 197

Doris areolata (I) 196 atromarginata (II) 300 aurantiaca (II) 301

latens (I) 196

lineolata (II) 297

nigra (I) 196

olivacea (I) 196

pecten (I) 197, (II) 308

rogersii (I) 196

striata (II) 308

Doto (II) 327 japonica (I) 202, (II) 327

Drepania (II) 297 japonica (II) 297

Drepanida (II) 297

Duraucelia (II) 310 exsulans (I) 199. (II) 310

irrorata (II) 315

reticulata (I) 198,202 , (II) 310

tetraquetra (I) 197, 199

Echinodoris (II) 300

armata (I) 202, (II) 300

Elysia (I) 224

grandifolia (I) 201, 225

japonica (I) 202, 225

viridis (I) 200,225

yaeyamana (I) 226

Eolidia pinnata (II) 333

Eolidina (II) 336 japonica (I) 202, (II) 336 takanosimensis (II) 336

Euphurus (II) 289 ornatus (II) 289

Euplocamus (II) 292 japonicus (I) 197, 198 
Favorinus (II) 333 pacificus (II) 333

Fiona (II) 333 marina (II) 333

pinnata (I) 197, 200, (II) 333

Geitodoris (II) 302

lutea (II) 302

ohshimai (II) 302

Glaucus (II) 336

lineatus (II) 336

marinus (I) 200, (II) 336

Glossodoris (II) 297

alderi (I) 197, 198, 201, (II) 297

aureopurpurea (I) 198, (II) 298

clitonota (I) 201, (II) 298

festiva (I) 197, 198, 202, (II) 297

lineolata (I) 201, (II) 297

pallescens (I) 198, 201, (II) 297

pantharella (I) 197, 202, (II) 298

reticulata (II) 297

sibogae (I) 201, (II) 298

thaiassopora (I) 197, 202, (II) 297

Goniodoris (II) 294

castanea (I) 200, 201, (II) 294

glabra (II) 294

Guyonia (II) 308

Gymnodoris (II) 292

alba (I) 201, (II) 292

citrina (I) 201, (II) 292

inornata (I) 198, 201, (II) 292

japonica (II) 292

maculata (I) 196, 202, (II) 292

okinawae (II) 292

striata (II) 292

Halgerda (II) 307

graphica (I) 201, (II) 307

japonica (I) 202, (II) 307

Hermaea (I) 223 dendritica (I) 200,223

Hervia (II) 328

Hexabranchus (II) 289

lacer (I) 197

marginatus (I) 201, (11) 289

Hirudo marina (II) 336

Homoeodoris (II) 307

japonica (I) 198, 202, (II) 307

Homoiodoris (II) 307
Kalinga (II) 293

ornata (I) 201 , (II) 293

Kaloplocamus (II) 293

Laplysia (I) 207

Limax tetraquetra (II) 312

Linguella babai (II) 320

fallax (I) 198 , (II) 320

iaira (II) 320

variolosa (II) 320

Madrella (II) 327

sanguinea (I) 201, (II) 327

Marionia (II) 312

granularis (II) 312

pustulosa odhneri (II) 313

Marioniopsis (II) 315

babai (II) 315

Melibe (II) 326

japonica-(1) 202, (II) 327

papillosa (I) 197,198 , (II) 327

pilosa (I) 198, 201, (II) 327

vexillifera (I) 198, 202, (II) 327

Nembrotha (II) 292

luteolineata (II) 292

Notarchus (I) 218

leachii var. freeri (I) 201, 218

lineolatus (1) 196

longicaudus (I) 196, 201, 221

stimpsoni (I) 221

Notobryon (II) 321 wardi (I) 201, (II) 321

Noumea (II) 298

nivalis (II) 298

Okadaia (I) 197, (II) 297 elegans (I) 199 , (II) 297

Okenia (II) 295 barnardi (II) 295

Oscanius sp. (I) 227

Pelta (I) 202

Peltodoris (II) 304 mauritiana (I) 199, 201, (II) 304

Petalifera (I) 216

punctulata (I) 197,126 
Petelodoris (II) 302

triphylla (I) 198,202 , (II) 302

Phyllapiysia punctulata (I) 197, 216

Phyliidia (II) 309

japonica (II) 310

nobilis (I) 201, (II) 310

pustulosa (I) 201, (II) 310

tuberculata (II) 310

varicosa (I) 201, (II) 310

Phylliroe (II) 326 bucephala (I) 200, (II) 326

Phyllodesmium (II) 335 hyalinum (I) 201, (II) 335

Placobranchus (I) 224 guttatus (I) 196 ocellatus (I) 196, 201, 224

Platydoris (I) 307 striata (II) 308

Pleurobranchaea (I) 229 japonica (II) 337 novaezealandiae (I) 229 novaezealandiae var. granulosa (I) 229

Pleurobranchus (I) 229 delicatus (I) 227

Pleuroleura (II) 316 striata (II) 316

Pleurophyilidia (II) 317 comta (I) 198 similis (II) 320 taeniolata (II) 318

Plocamopherus (II) 293

Plocamophorus (II) 293 imperials (I) 201, (II) 293 tilesii (I) 197, 198, 202, (II) 293

Polycera (II) 290 fujitai (II) 290

Pseudobornelia (II) 321 orientalis (II) 321

Pteraeolidia (II) $33 \%$ semperi (I) 201, (II) 335

Rizzolia (II) 328 modesta (I) 198, (II) 329
Rostanga (II) 300 arbutus (I) 201, (II) 300

Runcina (I) 202 elioti (I) 202

Sancara iaira (I) 197 , (II) 320

Scyllaea (II) 321 bicolor (I) 198, (II) 321

Stiliger (I) 222 akkeshiensis (I) 223 berghi (I) 222

Stylocheilus longicaudus (1) 221

Tethys (I) $20 t$ dactylomela (I) 196, 201, 208 euchlora (I) 197, 202, 208 hirasei (I) 211 japonica (I) 197, 211 kurodai (I) 213 laevigata (I) 196, 208 marginata (I) 197, 208 marmorea (I) 197 nigrocincta (I) 208 norfolkensis (1) 208 parvula (I) 199, 201, 208 sibogae (I) 201, 211

Thordisa (II) 304 amakusana (II) 304

Trapania (II) 296 japonica (II) 29 T

Trevelyana (II) 292 felis (I) 197 inornata (I) 198

Triopa (II) 289

Trippa (II) 302 intecta (I) 201, (II) 302

Tritonia exsulans (II) 310 reticulata (I) 198 , (II) 310 tetraquetra (I) 197, (II) 312

Tritoniopsilla (II) 312 tetraquetra (II) 312

Vayssierea (I) 197 


\section{EXPLANATION OF PLATES}

\section{Plate 1.}

Fig. 1. Dendrodoris miniata (AldeER \& Hancocx). $\times 1$.

Fig. 2. Madrella sanguinea (ANGAS). $\times 3$.

Fig. 3. Discodoris pardalis (ALDER \& HaNCOCK). $\times 1$.

Fig. 4. Dendrodoris gemmacea (AIDER \& HANCOCK). $\times 1$.

Fig. 5. Goniodoris castanea AldeR \& HaNcock. $\times 1$.

Fig. 6. Gonicdoris glabra nov. sp. $\times 2$.

Fig. 7. Crosslandia viridis EL LoT. $\times 2$.

Fig. 8. Gymnodoris inornata (BERGH). $\times 2$.

Fig. 9. Gymnodoris citrina (BERGH). $\times 6$. (drawn from a Tomioka specimen with a rather unusual coloration).

Fig. 10. Bacolidia major amakusana nov. subsp. $\times 1$

Fig. 11. Discodoris pallida nov. sp. $\times 3$.

Fig. 12. Thordisa amakusana nov. sp. $\times 1.3$.

Fig. 13. Dendrodoris guttata (ODHNER). $\times 1$.

Fig. 14. Actinocyclus japonicus (ELIDT). $\times 1$.

\section{Plate 2.}

Fig. 1. Dermatobranchus striatus van HASSELT. $\times 4$.

Fig. 2. Cuthona yatsui (BAB). $\times \mathbf{5}$.

Fig. 3. Nolobryon wardi ODHNER. $\times 1$.

Fig. 4. Cuthona ornata nov. sp. $\times 8$.

Fig. 5. Phyllodesmium hyalinum EHRENBERG. $\times 2$.

Fig. 6. Okenia barnardi nov. sp. $\times 6$.

Fig. 7. Favorinus pacificus nov. sp. $\times 8$.

Fig. 8. Euphurus ornatus nov. sp. $\times 7$. 
Plate 1
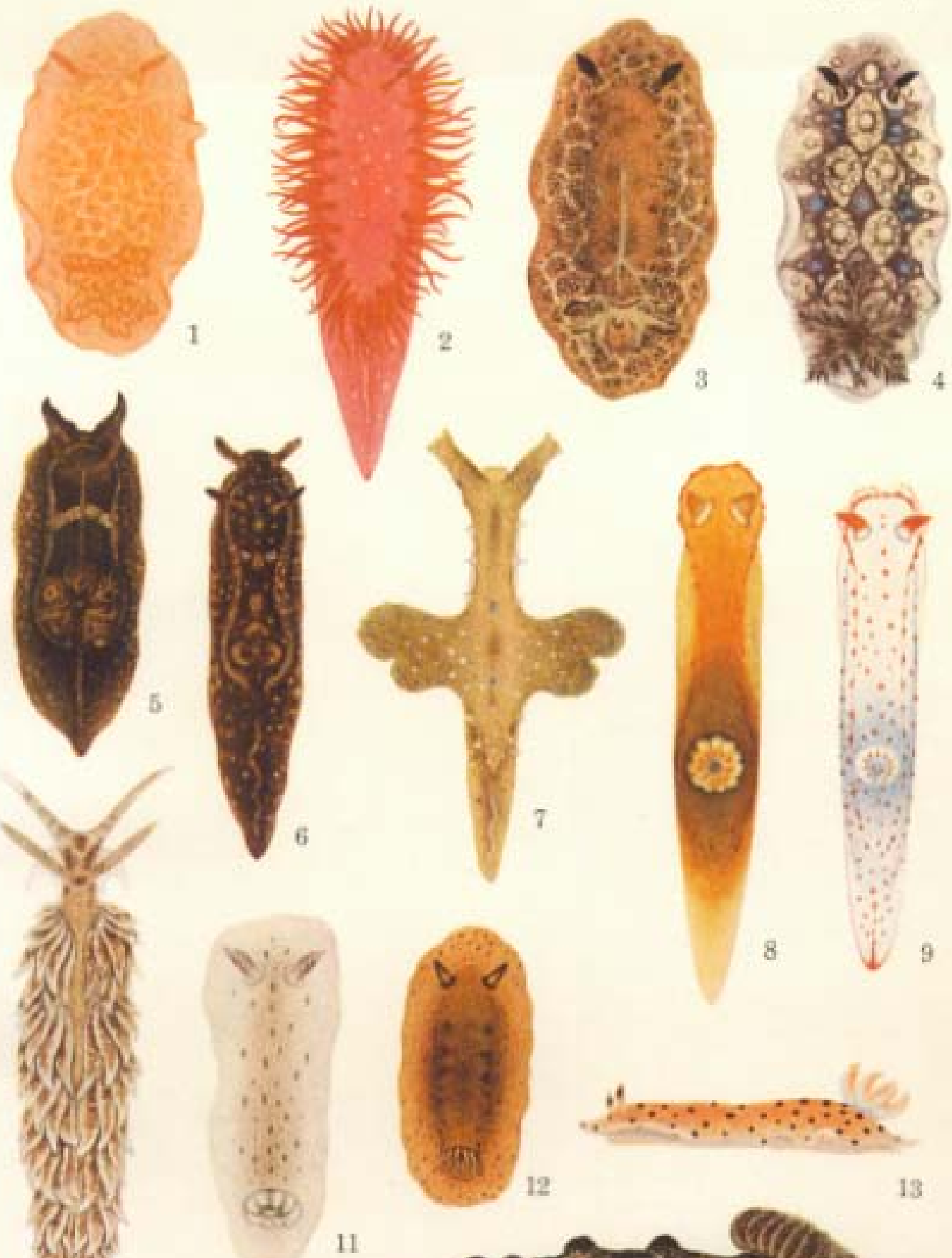

8

9
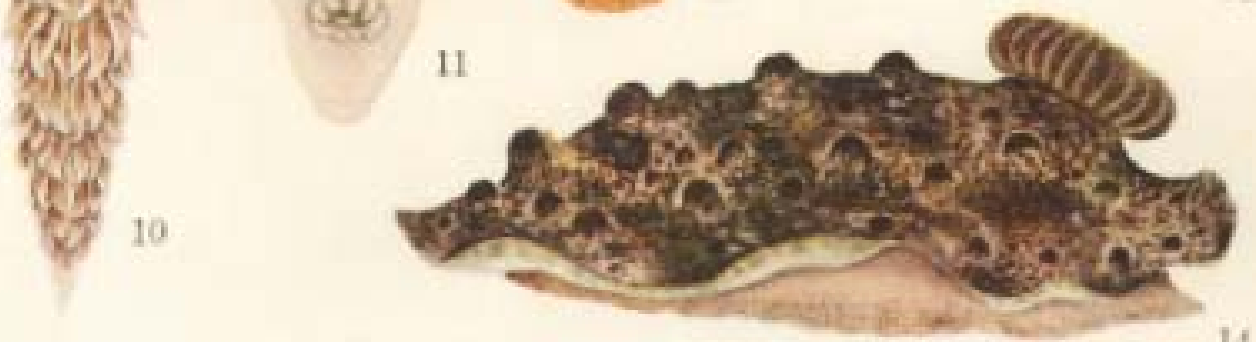
Plate 2

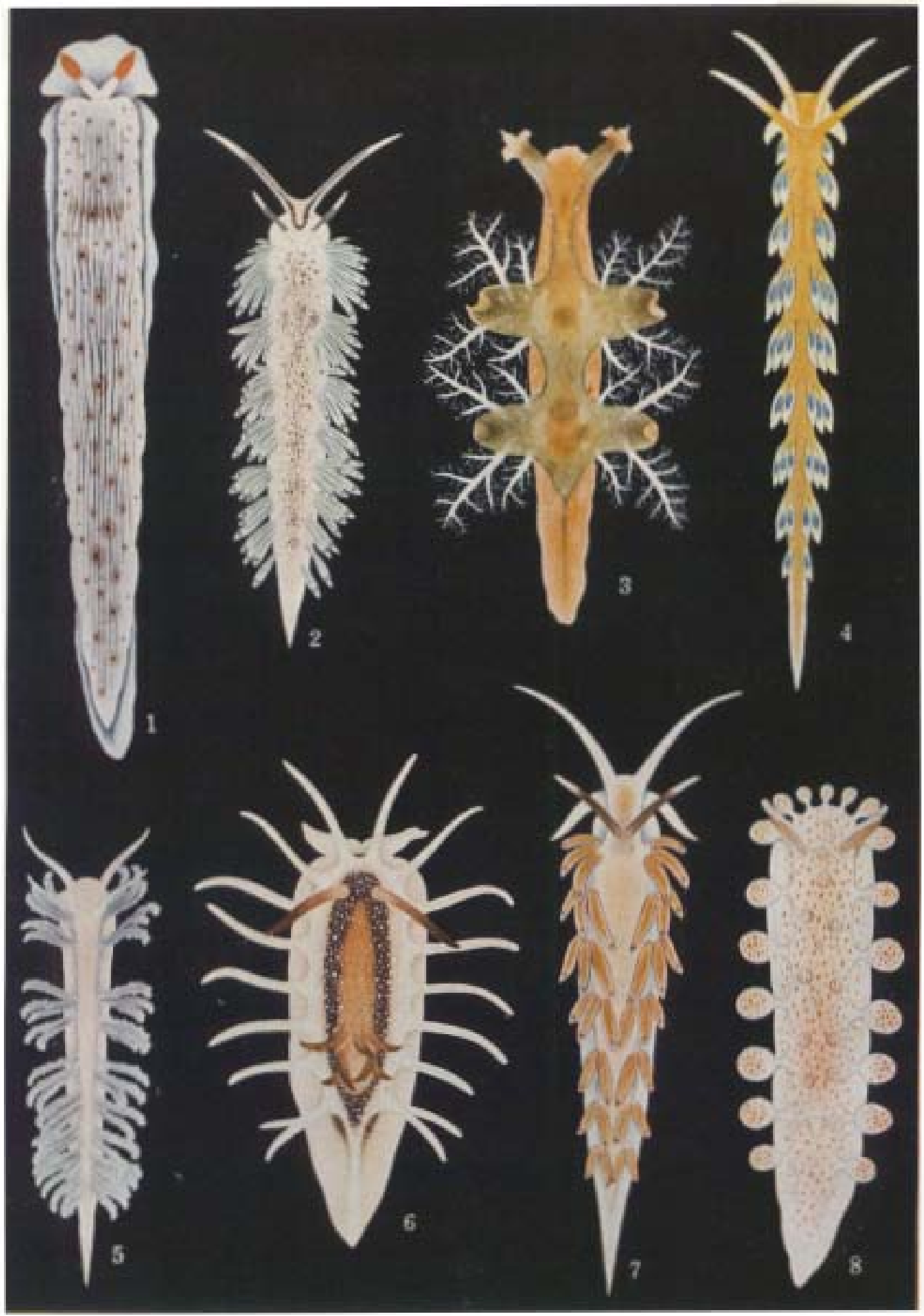

